\title{
ÁNGELES APÓCRIFOS EN LOS CONVENTOS DE MONJAS
}

\author{
POR \\ MARIO ÁVILA VIVAR ${ }^{1}$ \\ Centro de Restauración y Conservación de Castilla-La Mancha
}

\section{RESUMEN}

La preponderancia de estudios sobre las series angélicas virreinales, y la creencia generalizada de que las representaciones de ángeles apócrifos constituyen una peculiaridad específica de la angelología virreinal, ha creado una relación tan estrecha entre ésta y los ángeles apócrifos, que se han llegado a considerar sinónimos. Sin embargo, tanto los textos como la presencia de estos ángeles en los conventos españoles del siglo XVII, ponen en evidencia que los ángeles apócrifos surgieron y se representaron en España mucho antes que en sus virreinatos americanos. Y que por tanto es aquí donde deben buscarse sus fuentes y su significado.

PALABRAS CLAVE: ángeles apócrifos; series angélicas; angelología virreinal; monacato femenino.

\section{APOCRYPHAL ANGELS IN NUN CONVENTS}

\begin{abstract}
The preponderance of studies about viceregal angelic series, and the widespread belief that the representation of apocryphal angels is a specific peculiarity of viceregal angelology, have created such a close relation between it and the apocryphal angels, that they are even considered as synonymous. However, both the texts and the presence of this angels in the spanish convents of the XVII century, evidence that the apocryphal angels appeared and they were represented in Spain long before that in its american viceregal. Therefore, it is here where their origins and their meaning should be sought.
\end{abstract}

KEY WORDS: Apocryphal Angels; Angelic Series; Viceregal Angelology; Female Monasticism.

COMO CITAR ESTE ARTículo / CitATION: Ávila Vivar, M. 2017. «Ángeles apócrifos en los conventos de monjas». Hispania Sacra 69, 140: 647-660. doi: 10.3989/hs.2017.040

\author{
Recibido/Received 19-12-2015 \\ Aceptado/Accepted 22-12-2015
}

Conocimos la existencia de las series barrocas de ángeles apócrifos por las publicaciones de historiadores del arte virreinal, quienes se habían interesado por la presencia en las iglesias andinas de numerosos cuadros de ángeles "arcabuceros», identificados con extraños nombres. Para la historiografía virreinal esos ángeles eran la viva expresión del mestizaje cultural entre lo español y lo andino, y se ofrecieron diferentes explicaciones a sus fuentes y a su significado. Unos historiadores los asociaron con los ángeles planetarios del Libro de Enoch, y con los cultos precolombinos a los fenómenos naturales, los astros y las estrellas. ${ }^{2}$ Otros, desdeñando el significado de los

1 marioavilavivar@gmail.com / ORCID iD: http://orcid.org/0000-0001 $-6479-8048$

2 Mesa y Gisbert 1976 y 1983. nombres, dieron más importancia a sus atributos militares, y los consideraron ángeles-soldado que combatían junto al Imperio español en su expansión por el Nuevo Mundo. ${ }^{3}$ La preponderancia de estudios sobre los ángeles arcabuceros y sobre otras tipologías virreinales de ángeles apócrifos, crearon una relación tan estrecha entre los ángeles apócrifos y la angelología virreinal, que llegaron a considerase prácticamente sinónimos. Sin embargo, tanto la abundancia de series de ángeles apócrifos en los conventos españoles de religiosas, como los textos del siglo XVII y XVIII que consulté durante la investigación de mi tesis doctoral ${ }^{4}$, evidencian que los ángeles apócrifos, mucho antes que en los recintos andinos, se representaron en los conventos de

\footnotetext{
3 Mujica Pinilla 1996.

4 Ávila Vivar 2016
} 
monjas españolas, y que por tanto allí debían buscarse sus fuentes y su significado.

Hasta donde sabemos, las series angélicas barrocas se iniciaron en los monasterios reales madrileños de la Encarnación, las Descalzas Reales y Santa Isabel, para representar a los Siete Príncipes de los Ángeles, cuya existencia había revelado el ángel Rafael en el Libro de Tobías:

"Yo soy Rafael, uno de los siete ángeles que presentamos las oraciones de los justos, y tienen entrada ante la majestad del Santo» (To. 12,15).

Sus efigies y sus nombres eran bien conocidos desde que Amadeo de Portugal los escribió en el Apocalypsis nova (Roma, hacia 1475), y desde que se descubrió la pintura mural de la iglesia de San Ángel de Palermo en 1516, donde estaban representados. Y como es sabido, entre ellos había cuatro apócrifos, Uriel, Barachiel (o Baraquiel), Jehudiel y Sealtiel. Las series de los Siete Príncipes las realizó Bartolomé Román o Romano (Montoro, Córdoba, 1587? - Madrid, 1647) a principios del siglo XVII, y no fue casualidad que surgieran en esos monasterios. En las Descalzas fue donde Juana de Austria (1535-1573), siguiendo el ejemplo de su hermano Felipe II en El Pardo, instaló su magnífica Galería de Retratos ${ }^{5}$, que reunió más de un centenar de retratos familiares realizados por los más importantes pintores de la época, como Antonio Moro, Sofonisba Anguissola o Sánchez Coello. En la Galería colgaban retratos de emperadores, reyes, príncipes, y muchos otros personajes de la alta nobleza; y a principios del siglo XVII alguien debió pensar que sería conveniente que junto a los príncipes de este mundo, figurasen también los retratos de los príncipes del cielo. Porque conviene recordar que la función primordial de estos "retratos de representación» era la de manifestar las cualidades, la admiración y el temor ante el poder que detentaba el personaje representado; pero sobre todo la de mostrarle como un miembro de su clase, y como ejemplo de caballero cristiano; y si había un miles Christi por excelencia, este era el ángel. Por otra parte, en la sociedad cortesana del Barroco, regida por el patronazgo y el clientelismo, nada mejor que contar con buenos patronos para tener protección y alcanzar mercedes; y como los Siete Príncipes eran considerados validos, vicedioses y virreyes del rey del cielo, contar con su custodia era un formidable privilegio. Y seguramente por estas razones, la devoción a los Siete Príncipes fue una de las principales de estos monasterios. En el de las Descalzas, además de la serie de Bartolomé Román y de otra representada en los muros de la Escalera Real, se instaló un excelente cuadro de los Siete Príncipes de los Ángeles pintado por Francisco Guarino (1611-1654), y se eligió a uno de ellos, Jehudiel, como «Santo Ángel protector del convento». El patronazgo de este ángel fue autorizado por el papa San Pío V (1566-1572), y Gaspar Becerra (1520-1570) pintó su retrato para presidir su capilla. Allí se celebra aún su fiesta con misa solemne cada 23 de agosto, y es reverenciado por la comunidad como «Remunerador» y como "Guarda mayor de vírgenes». ${ }^{6}$

Siguiendo el ejemplo de estos monasterios, se realizaron otras muchas representaciones de los Siete Príncipes por toda España y por sus virreinatos americanos, tanto en grupo

\footnotetext{
5 Kusche 2003.

6 Ver Ávila Vivar 2011.
}

como formando series. ${ }^{7}$ Como las españolas de la catedral de Cuenca, iglesia parroquial de Campillo de Altobuey (Cuenca), iglesia de San Bartolomé de Borriol (Castellón), convento del Santo Ángel Custodio de Loja (Granada), monasterio de San Jerónimo de Granada, y monasterio de Santa Cruz de Córdoba; o la mexicana de Oaxaca, la colombiana de la iglesia de Santa Clara de Bogotá, y la peruana de la iglesia de San Pedro de Lima, replica de la que realizó Bartolomé Román para las Descalzas. Pero una vez sentado el precedente de representar en imágenes ángeles apócrifos, cundió el ejemplo, y paralelamente a estas series, se realizaron otras conformadas por ángeles menos aristocráticos, más cercanos y más relacionados con las monjas.

Es el caso de la serie del Hospital sevillano del Santísimo Cristo de los Dolores, de franciscanas terciaras del Tránsito, conocido popularmente como del Pozo Santo, donde a mediados del siglo XVII se instaló una serie formada por Micael, Gabriel Vir Deus, Rafael Medicina Dei, Alamiel Pax Dei, Ariel Visio Dei, Eliel Potentia Dei. Esriel Auxilium Dei, Hadriel Hablatio Dei, laciel Aspercio Dei, Oziel Fortitudo Dei. Y a pesar de que la Iglesia sólo reconocía a los ángeles canónicos, Miguel, Gabriel y Rafael, no debería sorprendernos que se representasen ángeles con otros nombres. En primer lugar, porque era bien conocido por todas las personas de aquella época con alguna cultura religiosa, que los nombres de los ángeles no son nombres propios, sino que se construyen a voluntad agregando el sufijo hebreo Èl (Dios), a los atributos divinos, oficios y beneficios angélicos. $Y$ que esos nombres debían escribirse en hebreo, porque el hebreo era considerado la lengua de los ángeles, el idioma primario de la Revelación con el que Dios se comunicó con Adán y con los patriarcas. ${ }^{8} Y$ en segundo lugar, porque aunque los nombres apócrifos fueron condenados en el Concilio Romano del año 745 , la tradición cabalista española, la aceptación por la Santa Sede de la devoción de los Siete Príncipes a mediados del siglo XVI, y la proliferación de sus imágenes, contribuía a que en la práctica fuesen permitidos. Así se deduce de la abundancia de representaciones de ángeles apócrifos en recintos religiosos, y de los textos de la época. Como leemos por ejemplo en el proceso inquisitorial de 1644 contra el pintor Francisco Barreda, por tener a la venta en su tienda de Madrid cuadros de los Siete Príncipes, donde una comisión calificadora dictaminó:

«que les parece que no hay inconveniente en tolerar las pinturas de todos los siete angeles con las señas y nombres... ya que estas mismas pinturas con las mismas señas i nombres de todos siete angeles se toleran en Roma a la vista de Su Santidad i en la ciudad de Palermo donde hai iglesia dedicada a ellos i en la iglesia catedral de la misma ciudad en la capilla del señor arçobispo Aedo que fue Inquisidor de aquel reino estan las mismas pinturas i en otras ciudades de Italia como refiere Cornelio a Lapide sobre el capitulo primero del Apocalipsis i otros padres sin que a esto obste la determinacion del Concilio Romano en tiempo del Papa Zacharias porque a eso dan varias salidas los authores $)^{9}$

Y el doctor Luis de Velazco y Villarín, otro de los calificadores convocados por el Santo Oficio, aunque

\footnotetext{
Ver González Estévez 2012.

8 Ver Gonzalo Rubio 1977.

9 Este pleito ha sido analizado por Mujica Pinilla 1996: 39-52.
} 
condenaba la representación de Uriel, Barachiel, Jehudiel y Sealtiel, recomendaba que no se condenase a los devotos de los ángeles apócrifos, "por estar en estampas publicas y aver libros de estos siete angeles». ${ }^{10}$

De las series de ángeles apócrifos conocidas, más de la mitad se encuentran en conventos de monjas, preferentemente en los de las clarisas. No sabemos cuántos cuadros aislados ni cuántas series de ángeles apócrifos se colgaron en los conventos en los siglos XVII y XVIII. Es bastante probable que muchos más de los que conocemos. Pero a mediados del siglo XVIII la Iglesia puso fin a la permisividad hacia estas devociones, y el Edicto del Santo Oficio del 15 de Julio de 1747 prohibió «qualquier Papel, Estampa, Estatua \&c. en que se hallen nombres de Angeles no reconocidos por la Iglesia», y en particular "toda Obra, Estampa, \&c. en que se dé culto á los Angeles Sealtiel, Uriel, Sehudiel, y Barachiel». ${ }^{11}$ La Inquisición precisaba que "es necesario que lo notado y mandado borrar en tal Libro, se borre en sus propios lugares, cada cosa en su lugar, de manera que no se pueda leer lo borrado». ${ }^{12}$ Así se hizo en muchas publicaciones, como se comprueba por ejemplo en un ejemplar de las Exortaciones a la devocion con los Santos Angeles $^{13}$, del jesuita Francisco García, conservado en la biblioteca Borbón Lorenzana de la Biblioteca Regional de Castilla la Mancha, donde en los folios 254-255 del capítulo dedicado al arcángel Rafael, figuran emborronados ostensiblemente los nombres de los ángeles apócrifos, con una anotación al margen que reza «Prohibidos por el Santo Tribunal año de 1777».

Y otro tanto debió suceder con las representaciones pictóricas. Es bastante probable que muchas series de ángeles apócrifos fueran dispersadas, muchos cuadros destruidos, y muchos nombres borrados $u$ ocultados bajo repintes. Como al parecer fue el caso de la serie representada en las columnas de la iglesia del monasterio de San Jerónimo de Granada; de la mural de la iglesia del convento de clarisas de Loja (Granada); o de otra serie que hubo en la iglesia del convento agustino de Guadix, que contenía cuatro apócrifos, Uriel, Anael, Caphiel y Laruel, el ángel custodio de "la Santa Juana». ${ }^{14}$ Este pudo ser también el caso de las series de la capilla de San Miguel de la catedral de Jaén ${ }^{15}$, y del monasterio de San José y San Roque de Aguilar de la Frontera (Córdoba) ${ }^{16}$; iconográficamente muy similares a la del Hospital de Pozo Santo. La capilla de San Miguel se construyó en 1761, y en esa fecha se embutieron en las paredes una serie de diez ángeles del siglo XVII, que

\footnotetext{
10 Ibídem.

11 Indice Último de los Libros Prohibidos y mandados expurgar: para todos los reynos y señorios del catolico rey de las Españas, el señor Don Carlos IV. Contiene en resumen todos los libros puestos en el Indice expurgatorio del año 1747, y en los edictos posteriores, asta fin de diciembre de 1789: En la imprenta de Don Antonio de Sancha, 1790.

12 Ibídem: 1790. Regla VIII.

13 Pozo, A. de. 1708. Exortaciones a la devocion con los santos angeles de nuestra guarda /... fol 254-255. En Madrid: por Diego Martinez Abad.

14 Serrano, A. 1707. Los siete Principes de los Angeles, Validos del Rey del Cielo. Misioneros, y Protectores de la Tierra, con la practica de su devoción.../. En Brusselas: por Francisco Foppens. Censura del R.P.M. Juan Bernardino de Gamiz.

15 Fernández López 1991: 211-218.

16 Lara Arrebola 1980.
}

FIGURA 1

POZO, Andrés de (S.I.), Exortaciones a la devocion con los santos angeles de nuestra guarda... Madrid, Imprenta de Diego Martínez Abad, calle de la Gorguera, 1708, pp. 254-255.

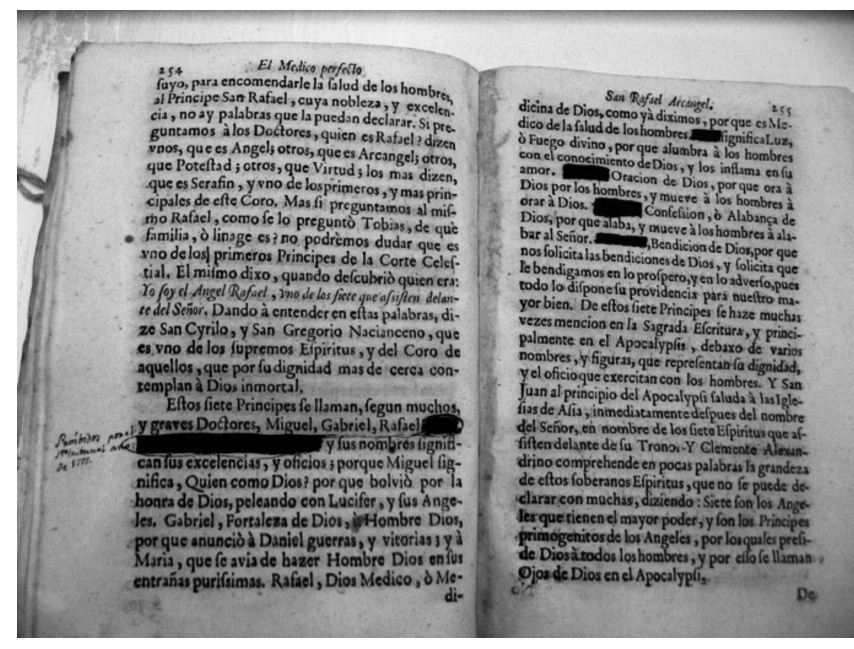

bien podían proceder de algún convento: San Miguel, San Gabriel, San Rafael, Ángel con libro pequeño, Ángel con gran libro, Ángel con espada flamígera, Ángel con cruz y cáliz, Ángel atando al demonio, Ángel con corona y palma, Ángel desenvainando la espada. Son cuadros muy repintados, a los que se añadieron inscripciones para ocultar la verdadera identidad de los ángeles. Por su parte, la serie del monasterio de Carmelitas Descalzas de Aguilar de la Frontera, también de mediados del siglo XVII, está formada por once ángeles identificados por pequeñas escenas bíblicas en la base del cuadro, pero sólo se conservan los nombres de los ángeles canónicos: Miguel, Gabriel bir Deus, Raphael Medisina Dei, Ángel de la Guarda, Ángel de la expulsión del Paraíso, Ángel de Isaac, Ángel de Jacob, Ángel de David, Ángel de Daniel, Ángel de la Navidad, Ángel de San Pedro. ${ }^{17}$

Aunque los historiadores andaluces dieron otras explicaciones al significado de estas series, lo más acertado es considerar que en todas ellas los ángeles personifican atributos divinos, ministerios y beneficios angélicos, que es lo que significan los nombres de los ángeles.

«Porque el nombre de los Angeles, que son embiados, con despachos del Cielo, se varían conforme las legacias à que vienen, segun el beneficio, que hazen, es el nombre [...] Bien probado queda, que los nombres de los Angeles tienen su origen en las mercedes, en los dones, en los efectos, en las diligencias, en los beneficios, que nos hacen [...] No hablamos de los nombres de su naturaleza, que son muy secretos [...] sino de los que tienen, por sus oficios, y beneficios [...] para que los conozcamos y sirvamos» ${ }^{18}$

\footnotetext{
17 Ávila Vivar 2014.

18 Blasco de Lanuza, F. de. 1652. Patrocinio de angeles y combate de demonios.... es vna ilustracion de los beneficios que hazen los Angeles de la Guarda à los hombres... / por... Fr. Francisco de Blasco Lanuza... de monges benitos claustrales...: Impresso en el Real Monasterio de San luan de la Peña: por luan Nogues.
} 


\section{CUADRO 1}

Series de ángeles apócrifos en conventos de monjas

\begin{tabular}{|c|c|c|}
\hline CONVENTO & $\begin{array}{l}\text { ORDEN } \\
\text { RELIGIOSA }\end{array}$ & SERIE ANGELICA \\
\hline $\begin{array}{l}\text { Monasterio de las Descalzas Reales } \\
\text { (Madrid) }\end{array}$ & Clarisas & $\begin{array}{l}\text { Portería Reglar. } \\
\text { Miguel, Gabriel, Rafael, Barachiel, } \\
\text { Sealtiel y el Ángel Custodio } \\
\text { Escalera Principal } \\
\text { Miguel, Gabriel, Rafael, Uriel, } \\
\text { Barachiel, Jehudiel, Sealtiel, Ángel } \\
\text { Custodio, y Ángel Protector del } \\
\text { Convento }\end{array}$ \\
\hline $\begin{array}{l}\text { Monasterio de la Encarnación. } \\
\text { (Madrid) }\end{array}$ & Agustinas & $\begin{array}{l}\text { Miguel, Gabriel, Rafael, Uriel, } \\
\text { Barachiel, Jehudiel, Sealtiel }\end{array}$ \\
\hline $\begin{array}{l}\text { Monasterio de Santa Isabel. } \\
\text { (Madrid) }\end{array}$ & Agustinas & $\begin{array}{l}\text { Serie desaparecida. Se conservaron } \\
\text { Barachiel y Jehudiel hasta la guerra } \\
\text { civil de } 1936\end{array}$ \\
\hline $\begin{array}{l}\text { Convento del Santo Ángel Custodio. } \\
\text { Loja (Granada) }\end{array}$ & Clarisas & $\begin{array}{l}\text { Miguel, Gabriel, Rafael, Uriel, } \\
\text { Baraquiel, Jehudiel y Sealtiel }\end{array}$ \\
\hline $\begin{array}{l}\text { Convento de Santa Clara. } \\
\text { Carmona (Sevilla) }\end{array}$ & Clarisas & $\begin{array}{l}\text { Miguel, Gabriel, Rafael, Uriel, } \\
\text { Barachiel, Jehudiel, Sealtiel }\end{array}$ \\
\hline $\begin{array}{l}\text { Monasterio de la Santa Cruz } \\
\text { (Córdoba) }\end{array}$ & Clarisas & $\begin{array}{l}\text { Se conservan Rafael, Uriel, Jehudiel } \\
\text { y otros dos de los que no se sabe } \\
\text { los nombres }\end{array}$ \\
\hline Hospital del Pozo Santo (Sevilla) & $\begin{array}{l}\text { Franciscanas } \\
\text { Terciarias }\end{array}$ & $\begin{array}{l}\text { Micael, Gabriel Vir Deus, Rafael } \\
\text { Medicina Dei, Alamiel Pax Dei, Ariel } \\
\text { Visio Dei, Eliel Potentia Dei. Esriel } \\
\text { Auxilium Dei, Hadriel Hablatio Dei, } \\
\text { laciel Aspercio Dei, Oziel Fortitudo } \\
\text { Dei }\end{array}$ \\
\hline $\begin{array}{l}\text { Monasterio de San José y San } \\
\text { Roque } \\
\text { Aguilar de la Frontera (Córdoba) }\end{array}$ & Carmelitas & $\begin{array}{l}\text { Miguel, Gabriel bir Deus, Raphael } \\
\text { Medisina Dei, Ángel de la Guarda, } \\
\text { Ángel de la expulsión del Paraíso, } \\
\text { Ángel de Isaac, Ángel de Jacob, } \\
\text { Ángel de David, Ángel de Daniel, } \\
\text { Ángel de la Navidad, Ángel de San } \\
\text { Pedro }\end{array}$ \\
\hline $\begin{array}{l}\text { Iglesia de Santa Clara. } \\
\text { Bogotá (Colombia) }\end{array}$ & Clarisas & $\begin{array}{l}\text { Miguel, Gabriel, Rafael, Uriel, } \\
\text { Jehudiel, Seactiel, Ángel de la } \\
\text { Guarda }\end{array}$ \\
\hline $\begin{array}{l}\text { Monasterio de la Concepción. } \\
\text { Lima (Perú) }\end{array}$ & Concepcionistas & $\begin{array}{l}\text { Miguel, Gabriel, Rafael, Uriel, Ariel, } \\
\text { Hadriel y Zadquiel }\end{array}$ \\
\hline
\end{tabular}

Se admitía por tanto que aunque la Iglesia solo aceptaba como verdaderos el nombre de los ángeles canónicos, Miguel, Gabriel y Rafael, se podía denominar a cualquier ángel con un nombre que expresase su oficio, que eran a la vez «las mercedes, los dones, los efectos, las diligencias, y los beneficios, que nos hacen». Y los textos de la época reflejan también la necesidad que había de conocer esos nombres para invocarlos y para venerarlos, incluidos los apócrifos.

«Nosotros necesitamos de saber sus nombres, para saber con quien hablamos; y estos son los de los oficios, que con nosotros, o por nosotros exercitan, que son bien altos, y soberanos: y como es acto de religión nombrarlos por los oficios; lo es de piedad, y amor invocarlos por estos nombres, que los significan ${ }^{19}$

«Estos nombres [...] no tienen la autoridad [...] para ser admitidos de la Iglesia [...] mas supuesto que en imágenes $i$

19 Serrano, Andrés 1707: 260-261. Los siete Principes de los Angeles, Validos del Rey del Cielo. Misioneros, y Protectores de la Tierra, con la practica de su devoción.../. En Brusselas: por Francisco Foppens. Censura del R.P.M. Juan Bernardino de Gamiz. particular libros, i oficios, se ven [...] parece que en particular podriamos usar destos nombres [...] para [...] entendernos nosotros con ellos» ${ }^{20}$

Atributos divinos, oficios y beneficios, es lo que personifican los ángeles apócrifos en las series. Alegorías de atributos divinos son lo que representan los ángeles de la serie del Hospital del Pozo Santo: Auxilium Dei (Protección o auxilio de Dios), Fortitudo Dei (Fortaleza de Dios), Pax Dei (Paz de Dios), Potentia Dei (Poder o fuerza de Dios), etc. Y beneficios y oficios angélicos es lo que parecen representar las de Jaén y las de Aguilar de la Frontera. Los beneficios angélicos son las mercedes que los ángeles conceden a sus devotos, y gozar de ellos era uno de los principales argumentos que se esgrimía para fomentar la devoción angélica. San Buenaventura mencionaba trece: reprender a los pecadores, fomentar la caridad, combatir las tentaciones, fomentar las buenas obras, custodiar a los viajeros, etc. Y Blasco de Lanuza, doce:

«Primero [...] es incitar a lo bueno, y apartar de lo malo [...] Segundo [...] ofrecer a Dios nuestras oraciones [...] Tercero [...] quitar los peligros exteriores, espirituales, y corporales [...] Quarto [...] atar el poder del Demonio para que no tiente [...] Quinto [...] reprehender los pecados cometidos [...] Sexto [...] consuela [...] Septimo [...] guiarnos siempre, de noche, de dia, en qualquiera tiempo, en todo lugar [...] Octavo [...] mitigar las tentaciones [...] Nono [...] salir a nuestra defensa en forma visible [...] Decimo [...] sacarnos de gravissimos aprietos [...] Undecimo [...] exortar a todo genero de Virtudes [...] Duodecimo [...] castigar (como amoroso Maestro) para traer a enmienda $)^{21}$

En los devocionarios los beneficios van ilustrados con sus correspondientes exemplum; en general eventos bíblicos protagonizados por los ángeles. Así el castigo a David con la peste en Jerusalén por realizar un censo, era un ejemplo de cómo castigan los ángeles los pecados de los hombres. Sus intervenciones en auxilio de Daniel, Isaac, Loth, Jonás, etc., de la ayuda que prestan en "gravísimos aprietos». Y la lucha que sostuvo Jacob con el ángel, de su apoyo para vencer las tentaciones. Y como estos exemplum son precisamente los que están representados en las pequeñas escenas que acompañan a los ángeles, podemos establecer paralelismos entre las imágenes y los textos, y deducir que estas series andaluzas constituyen ilustraciones visuales de los atributos divinos, oficios y beneficios angélicos. Que ese era realmente su significado, y que su presencia en los conventos tenía una función devocional y catequética, ya que fueron realizadas para honrar a los ángeles, y para fomentar su fervor entre las religiosas. ${ }^{22}$

\section{ÁNGELES APÓCRIFOS CUSTODIOS DE LAS RELIGIOSAS}

Los textos también demuestran que los ángeles apócrifos eran adoptados con frecuencia como custodios por las monjas. Un caso bien conocido es el de María de Jesús de Agreda (1602-1665); posiblemente la monja

20 Roa, M. 1632. Beneficios del Sto. Ángel de Nuestra Guarda. 20. Córdoba: por Salvador de Cea.

21 Blasco de Lanuza, Francisco de. 1637. Beneficios del glorioso Angel de nuestra guarda... Edición de Diego Dormer. Zaragoza.

${ }_{22}$ Ver Ávila Vivar 2014. 
española más famosa del siglo XVII, por sus revelaciones, por sus «apariciones» en Nueva España evangelizando a los indígenas, o por su correspondencia con Felipe IV. ${ }^{23}$ Su Mística Ciudad de Dios ${ }^{24}$, un panegírico escotista en honor de la Virgen y de su Inmaculada Concepción, provocó exacerbadas polémicas y fue incluido en el Índice de 1713; pero en su tiempo fue aprobado por las universidades españolas, y se convirtió en un bestseller que alcanzó más de 200 ediciones hasta el siglo xx. ${ }^{25}$ Según sor María de Jesús escribió la obra por indicación directa de Jesucristo, pero su redacción no hubiera sido posible sin la ayuda y la supervisión angélica:

«Un dia vì à los Angeles Santos (que son seis) que el todo Poderoso me ha señalado, para que me assistan en esta obra, me encaminen en ella ${ }^{26}$

Los seis ángeles eran Graciel, Nunciel, Saciel, Baraquiel, Agael y Marachiel, los mismos que la servían de interlocutores con Cristo y con la Virgen en Jardín espiritual para recreo del alma... ${ }^{27}$, la obra con que inició su actividad literaria hacia los 20 años. En este libro sor María de Jesús cuenta que Jesucristo se los asignó como custodios cuando tenía veintiún años de edad, y tres como monja profesa; y que la reveló sus nombres y ministerios:

"Graciel, que se interpreta como "medianero y abogado entre Dios y el alma, y distribuidor de los bienes de gracia y luz del Altisimo. Nunciel, "nuncio entre Dios y el alma, y mensajero para presentar al Altisimo los deseos y obras y peticiones del alma. Este santo ángel es el de la guarda, que se me dio cuando el Señor me crió"; Saciel, "sabiduría de Dios y voz que la publica"; Baraquiel, "fortaleza de Dios, rigor contra los enemigos para guarda del alma"; Agael, "manifestador y alabanza de la grandeza del Altísimo. Está diciendo siempre este espíritu sobre las grandezas de Dios ¿cual cómo ella?"; y Maraquiel, "bendición del Señor y maravilla suya» ${ }^{28}$

Es bien significativo que esta Venerable concepcionista no mostrase temor alguno en escribir en la España de la Contrarreforma, que tenía como custodios a seis ángeles apócrifos, y más aún cuando era bien sabido que los nombres apócrifos derivan de los textos cabalistas, y María de Jesús era de ascendencia judía por vía paterna. Estos hechos ponen una vez más en evidencia que en la España del siglo XVII eran tolerados los ángeles apócrifos, y que eran aceptados sin problemas como custodios por las monjas.

Otro ángel apócrifo citado con frecuencia en los tratados angélicos fue San Laruel Aureo, el ángel custodio de Juana de la Cruz (1481-1534) ${ }^{29}$, abadesa del monasterio de Nuestra Señora de la Cruz de Azaña (actual Numancia de la

\footnotetext{
23 Pérez Villanueva 1979, vol. IV, cap. III. 361-418 y 359-417.

24 María de Jesús de Ágreda 1670. Mística Ciudad de Dios, milagro de su omnipotencia y abismo de la gracia. Historia divina y vida de la Virgen Madre de Dios. Madrid.

25 Pérez-Rioja anota 222 ediciones en los más diversos idiomas, y más de 267 estudios críticos y biografías.

26 María de Jesús de Ágreda 1670: 10

27 María de Jesús de Ágreda 2005. Jardín espiritual para recreo del alma. Edición de Ángel Martínez Moñux. Monasterio de la Concepción Ágreda Ágreda-Soria. Editorial Las Heras-Soria.

28 Ibídem 2005: 29-35.

29 Navarro, Pedro 1622. Favores de el rey de el cielo hechos a su esposa la Santa Juana de la Cruz...: con anotaciones theologicas y morales a la historia de su vida / por Fr. Pedro Navarro...: En Madrid: por Thomas lunti.
}

FIgURA 2

Vera efigie de Sor María de Jesús de Agreda. Grabado xilográfico intercalado en Mystica Ciudad de Dios, Amberes, 1696

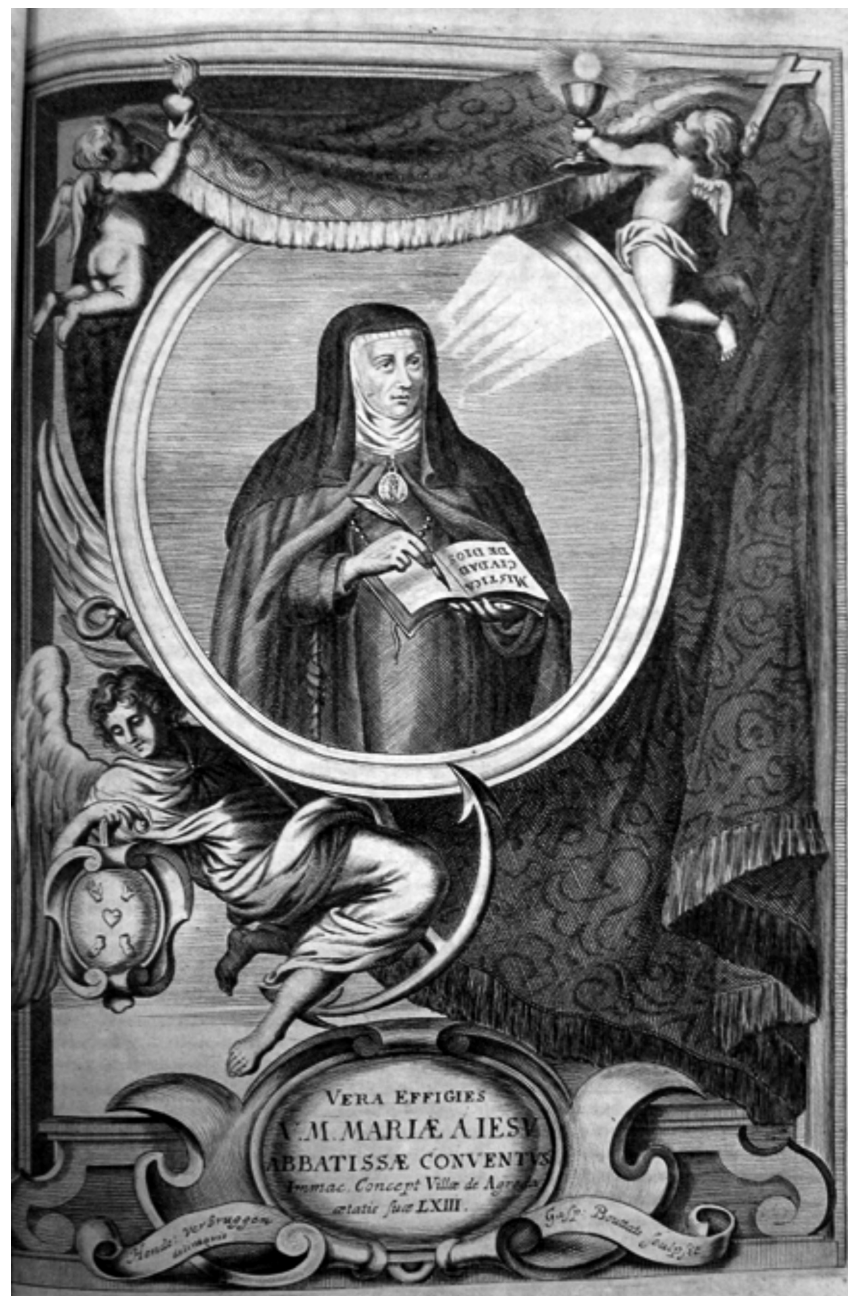

Sagra, Toledo). Este ángel se hizo muy popular por la fama que adquirieron las llamadas "cuentas de la Santa Juana», milagrosos abalorios que San Laruel llevó directamente al cielo el año de 1523 donde los bendijo Jesucristo, y que concedían indulgencias, curaban enfermedades, y eran un talismán contra las tentaciones y los demonios. Según sor Juana fue la misma Virgen quien la dio a conocer el nombre de su ángel custodio, un excelso serafín que anteriormente había sido custodio del Rey David, de San Jorge y de San Gregorio, y que era conocido en el cielo como el "Ángel privilegiado». San Laruel participaba de las virtudes de todos los coros angélicos, y su oficio era visitar y consolar a las almas del Purgatorio. Por todos estos motivos fue muy venerado por las monjas del monasterio, que a veces, por confusión, le denominaban San Laurel, y le adoptaron como custodio. A lo largo del tiempo muchas otras personas siguieron su ejemplo, como informaba Alonso Vidal Truxillo, presbítero de la iglesia parroquial de Lebrija (Sevilla), a principios del siglo XVIII:

"Innumerables fueron las personas devotas, que se aplicaron à ser muy finas servidoras del Angel de guarda de la sierva de Dios, Juana de la Cruz, las quales no solo 
se alistaron por sus devotas, tomandole por su patrón, y abogado, à quien como a tal servían esmeradamente, sino que sabiendo de la dicha sierva de Dios, que este su Angel de guarda, se llamaba San Laruel Aureo, dexaron las tales personas los apellidos de sus linages, y parentelas, y tomaron por sobre nombre el del Angel San Laruel ${ }^{30}$

San Laruel fue representado muchas veces como le había descrito "la Santa Juana», como un joven vestido de blanco o de morado, con lujosos ropajes adornados con cabujones y cartelas con inscripciones en latín, coronado con diadema de oro rematada en cruz, y portando como atributos un cetro de oro, un laúd o vihuela, o un estandarte adornado con insignias de la Pasión o de la Virgen. Gracias a Gabriela Braccio ${ }^{31}$, sabemos de la existencia de un cuadro que representa a Juana de la Cruz en presencia de San Laruel en el convento navarro de Santa Clara de Tudela; y de un cuadro de San Laruel en el convento franciscano de San Bernardino de Siena en Xochimilco (México) firmado por Manuel Carcanio en 1742. Como Laruel, Angel del Privilegio, tocando una citara, figuraba en la serie que hubo en la Iglesia del convento de los agustinos de Guadix (Granada). ${ }^{32}$

FIGURA 3

Juana de la Cruz y Jesucristo bendiciendo los rosarios que subió al cielo San Laruel. En Pedro Navarro, Favores de el rey del cielo hechos a su esposa la Santa Juana de la Cruz... En Madrid, por Thomas lunti, 1662, p. 40.

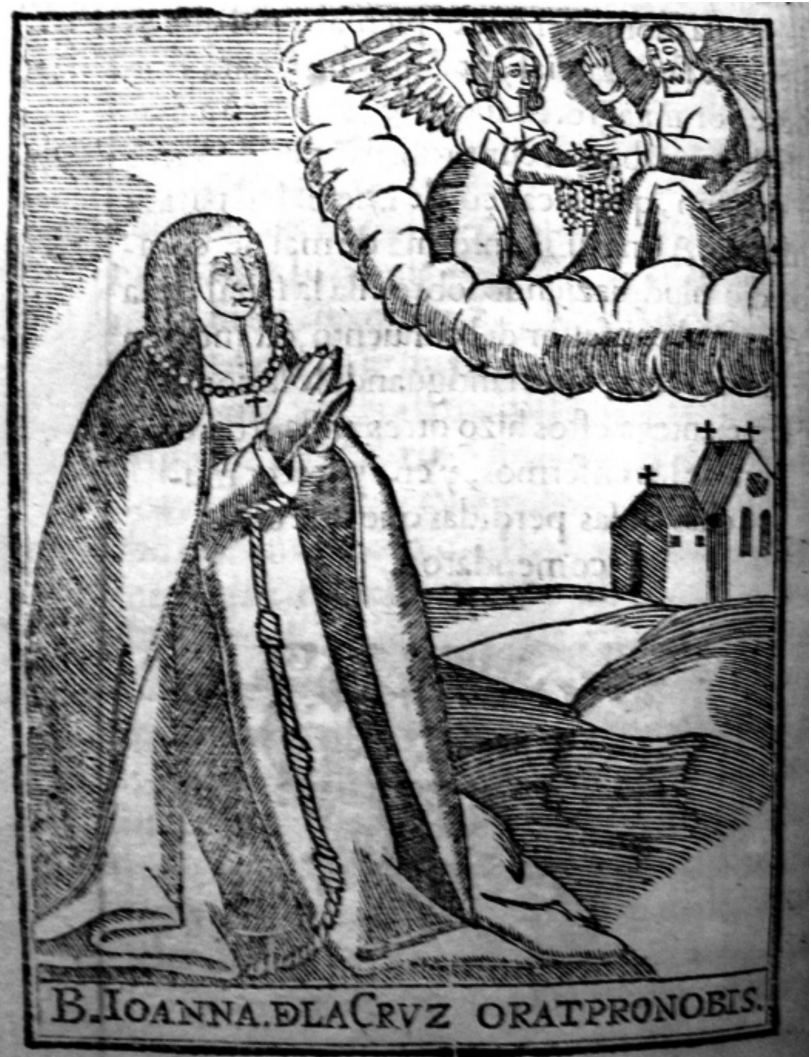

30 Vidal Truxillo y Grajales, Alonso 1716. Cadena angelical y sacra confederacion de especial gloria de los Angeles de Guarda de los fieles... 119-120. En Cordova: En la Imprenta de Estevan de Cabrera.

31 Ver Braccio 2010.

32 Serrano, Andrés 1707. Los siete Principes de los Angeles, Validos del Rey del Cielo. Misioneros, y Protectores de la Tierra, con la practica de su devoción.../. En Brusselas: por Francisco Foppens. Censura del R.P.M. Juan Bernardino de Gamiz.
FIGURA 4

Ángel San Larbel (Larvel) Areo. 190,00 cm x 145,00 cm BARCELONA, Código. 000000098749 del Catálogo de Bienes Culturales. Ministerio de Cultura.

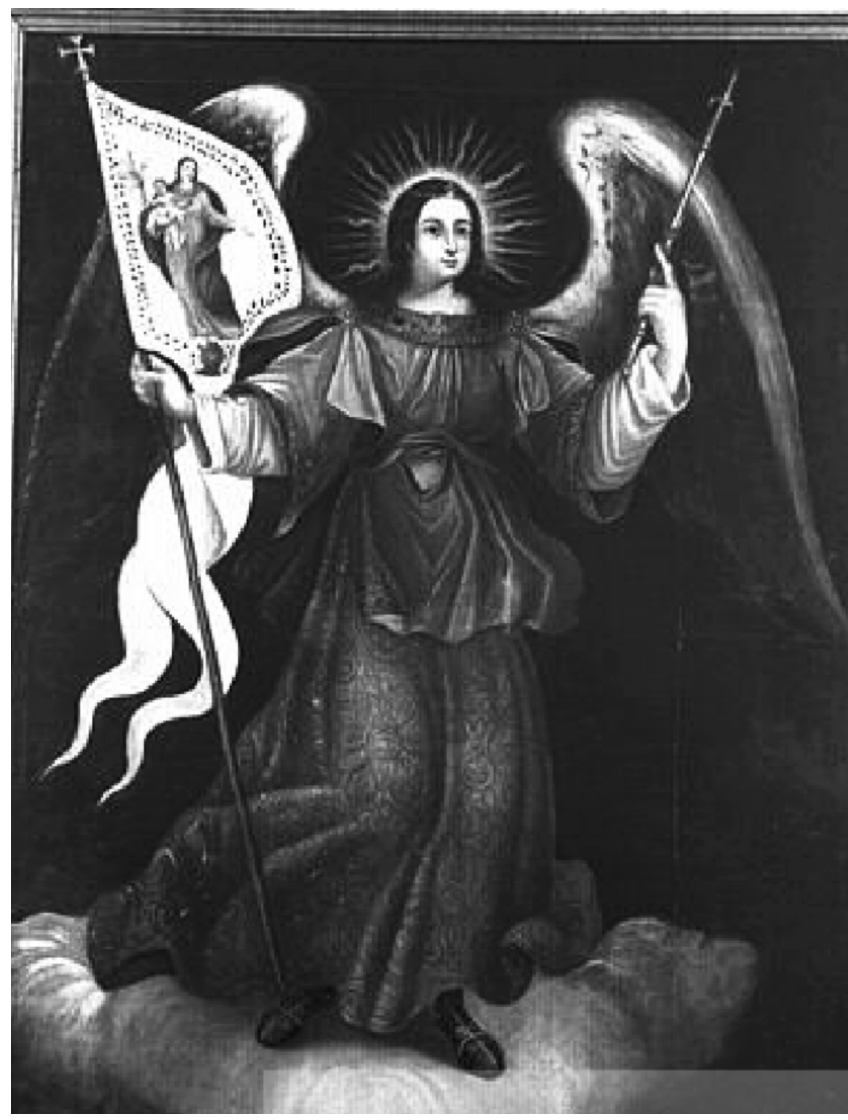

Como Lauro pretendieron representarle las monjas del monasterio madrileño de San Plácido, como veremos más adelante. Con el nombre de Laruel Misericordia Dei figura en la conocida serie de Sopó (Colombia), portando una rama de laurel y una palma. Y con el nombre de Ángel San Larbel Areo figura con el código 000000098749 en la base de datos del Ministerio de Cultura. La popularidad de San Laruel y de "la Santa Juana» fue tan grande, que Tirso de Molina la dedicó una de sus comedias ${ }^{33}$, y Villegas la incluyó entre los santos extravagantes en su Flos sanctorum. ${ }^{34} \mathrm{Su}$ fama se extendió incluso por los virreinatos americanos, como muestran dos procesos inquisitoriales celebrados en Lima a finales del siglo XVII; uno contra la beata Ángela Carrasco, y otro contra sor Juana Luisa Benítez, «la Pacora»; quienes declararon profesar gran devoción a sor Juana de la Cruz y a su ángel custodio.

Luisa Benítez era íntima amiga de otra monja llamada Ana Núñez, ambas profesas en el monasterio de Santa Clara de Trujillo (Perú), ambas auto inculpadas como posesas por legiones de demonios que las torturaban con delirios

33 Tirso de Molina, La Santa Juana. Segunda parte, Edición de Xavier A. Fernández, Kassel, Reichenberger, 1988.

34 Villegas, Alonso de. (1534-ca.1615), Flos sanctorum: tercera parte: Historia general en que se escriuen las vidas de sanctos extrauagantes y de varones Illustres en virtud... / por el maestro Alonso de Villegas...: Impresso en Toledo: por luan y Pedro Rodriguez... y a su costa, MDXXXVIII [i.e. 1588] (1587). 
sexuales, y ambas con un ángel apócrifo por custodio. El de la Pacora se llamaba Gloriel, «que significa Maestro de trabajos», y el de Ana Núñez, Siniel, "que quiere decir fortalecer las almas en cosas de virtud $» .^{35}$ Cuando el ataque de los demonios era muy fuerte, Gloriel los enfrentaba formando un escuadrón con toda la milicia celestial y los coros angélicos, y poniendo delante a la Pacora «a modo de paje morrión». ${ }^{36}$ Durante el combate Cristo arengaba a los ángeles por boca de la Pacora, y cuando finalizaba era llevada ante la Trinidad donde pesaban la gracia que había alcanzado con la victoria. Y como su confesor, fray Francisco, mostraba desconfianza a estos sucesos, le aseguró que Jesucristo "habló por mi boca al modo que el espíritu santo cuando habla por la boca de la venerable Juana de la Cruz». ${ }^{37}$ En las declaraciones de ambos ante el Santo Oficio, hay tantas comparaciones entre la Pacora y sor Juana de la Cruz, que da la sensación que pretendían equipararse. No solo los demonios de Trujillo adoptaban formas animales,

\section{FIGURA 5}

Dibujo de Ana Núñez que muestra la imagen de Luisa Benítez, "la Pacora", que vio sobre el pecho de su ángel custodio, Siniel. En Copia de diferentes dichos y hechos de la causa que en este Santo Oficio se sigue sobre las religiosas que se hallan obsesas en el convento de Santa Clara de la ciudad de Trujillo deste reyno del Peru. Proceso de fe de las religiosas de Santa Clara de Trujillo (Perú). A.H.N. Inquisición. Leg. 1648. Exp.6. no 2.

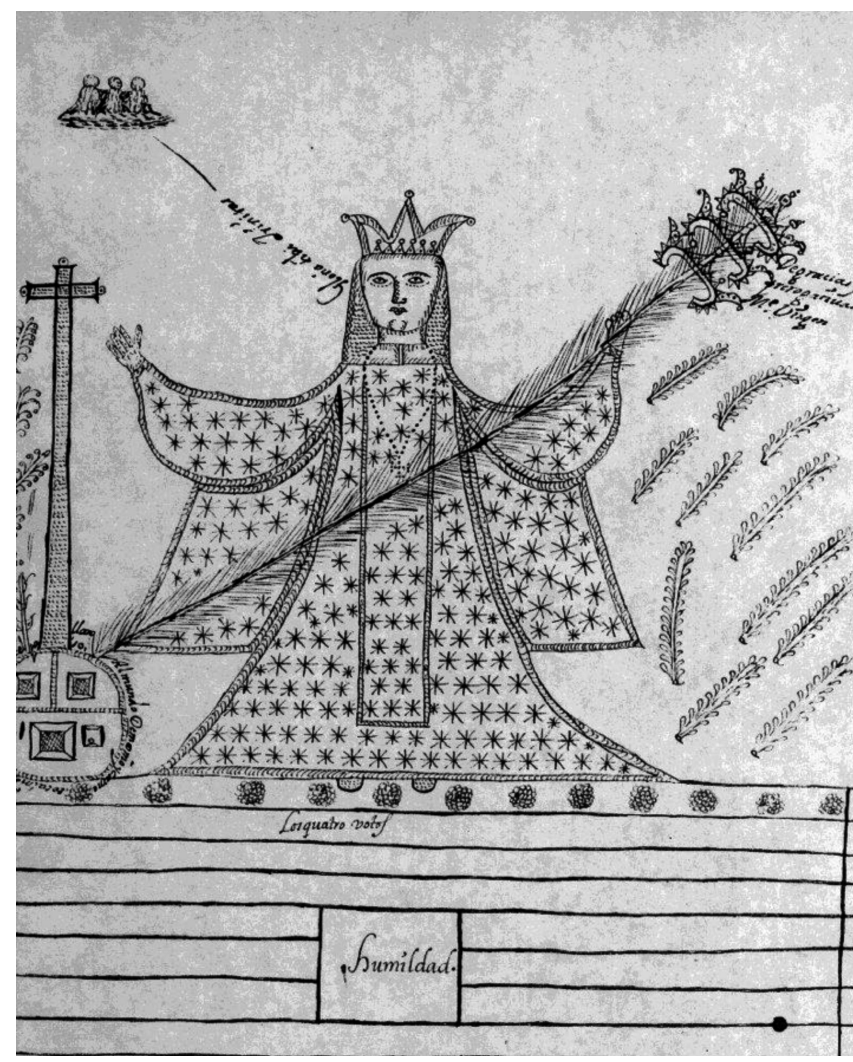

35 Copia de diferentes dichos y hechos de la causa que en este Santo Oficio se sigue sobre las religiosas que se hallan obsesas en el convento de Santa Clara de la ciudad de Trujillo deste reyno del Peru. Proceso de fe de las religiosas de Santa Clara de Trujillo (Perú). A.H.N. Inquisición. Leg. 1648. Exp.6. Fol. 23 v.

36 Ibídem. Fol.19v.

37 Ibídem. Fol. 20r. como en el caso de los que visitaban el monasterio de Cubas de la Sagra, sino que incluso el ángel custodio de la Pacora tenía una iconografía similar al de sor Juana. De hecho, tanto fray Francisco como la Pacora se declaraban grandes devotos de "la Santa Juana», y ambos poseían la biografía publicada por fray Pedro Navarro. Por su parte, Ana Núñez ${ }^{38}$ aseguraba que Siniel tenía pintada en su pecho la imagen de la Pacora, de cuya cintura salía una cadena que se ataba en la garganta de su alma para abrazarla y defenderla de los demonios. Porque según le reveló Siniel, estos demonios solo obedecían a la Pacora, y por eso no salían de su cuerpo cuando los sacerdotes realizaban los exorcismos. Ana Núñez incluso realizó un dibujo de la imagen de la Pacora, que Siniel llevaba en el pecho.

Del mismo modo que las citadas, otras muchas religiosas tuvieron como custodios ángeles apócrifos. Una de ellas fue la también célebre Luisa de la Ascensión (1565-1636), conocida popularmente como "la monja de Carrión», que compaginó su fama de taumaturga y mística, con sus relaciones públicas y sus dotes de bilocación. Fue abadesa del monasterio de clarisas de Carrión de los Condes (Burgos), y mantuvo con Felipe III una relación similar a la de María Jesús de Agreda con Felipe IV. En los Memoriales ${ }^{39}$ y Relaciones ${ }^{40}$ que se escribieron para defender o condenar su beatificación, leemos que tenía un ángel custodio que se llamaba Garniel, y sabía su nombre «porque havia mas tiempo de 20 años que nuestro Señor se lo havia dicho». ${ }^{41}$ Garniel le revelaba grandes secretos espirituales y la defendía también de los frecuentes ataques de los demonios:

«Desde que entro en la Religion, hasta que murio, en dando las doze de la noche se le aparecian los demonios, con gran ruydo y estruendo, con feas y espantosas figuras, unos con açotes, otros con garfios, otros con cadenas, otros con bastones de hierro, otros con dientes de lo mismo, tan hechos fuego como si los sacaran de una fragua, y descargaban sobre su cuerpo todos estos generos de martirios, y dexandola tendida en el suelo, toda herida, despedaçada, y dessangrada, y abrasadas muchas partes de su cuerpo, la arrastraban por la tierra, y arroxaban por la escalera de la ermita abaxo, y que la arrancaron todos los dientes y muelas, y todas las uñas de los dedos de los pies, y quando estas tornaban a nacer, se las bolbian a arrancar de nuevo, y que acabados estos tormentos la hechaba nuestro Señor la bendicion, con que quedaba sana ${ }^{42}$

La carmelita toledana Isabel de Jesús (1611-1682) también tuvo un ángel custodio apócrifo, que le reveló su nombre al noveno día de profesar. El día que profesó tuvo una visión del monte Carmelo, donde la llevaron su ángel y Santa Leocadia. Allí pudo ver a la Virgen del Carmen sobre una nube acompañada de San José, Santa Teresa, y otros muchos santos y santas. Por la tarde durante la ceremonia de profesión, tuvo de nuevo un rapto y se repitió la visión. En ella Santa Leocadia y el ángel le pusieron el manto de

38 Ibídem. Fol. 22v-25r.

39 Balbas, Pedro 1643. Memorial informativo en defensa de sor Luisa de la Ascension, monja professa de Santa Clara de Carrion / hecho por Fray Pedro de Balbas... como procurador en dicha causa por la religion de San Francisco...: En Madrid: por Diego Diaz de la Carrera.

${ }^{40}$ RELACIÓN de la causa de Sor Luisa de la Ascension, monja del Convento de Santa Clara de Carrion que se da para calificar. ¿1633?

41 Ibídem: 51.

42 Ibídem: 32-37. 
carmelita, y a continuación celebró los desposorios místicos con Cristo. Durante nueve días estuvo como arrobada, y el último preguntó al ángel su nombre, quien le respondió "Laureo me llamo, llamame Laureo tuyo, que yo te llamaré Alma mia». ${ }^{43}$ Su nombre deriva sin duda del ángel custodio de Juana de la Cruz, Laruel Aureo; y ni su confesor, fray Manuel de Paredes, ni ninguno de los ilustres y numerosos censores y calificadores que aprobaron la edición de su $V_{i d a}{ }^{44}$, vieron ningún problema en que su ángel custodio fuese apócrifo.

\section{FIGURA 6}

Franciscus de Castro. Vera efigie de la Venerable Virgen sor Isabel de Jesús Toledana Terciara. Grabado xilográfico. Toledo, 1683. Intercalado en Isabel de Jesús, (O.C.): Tesoro del Carmelo escondido... Madrid, 1685.

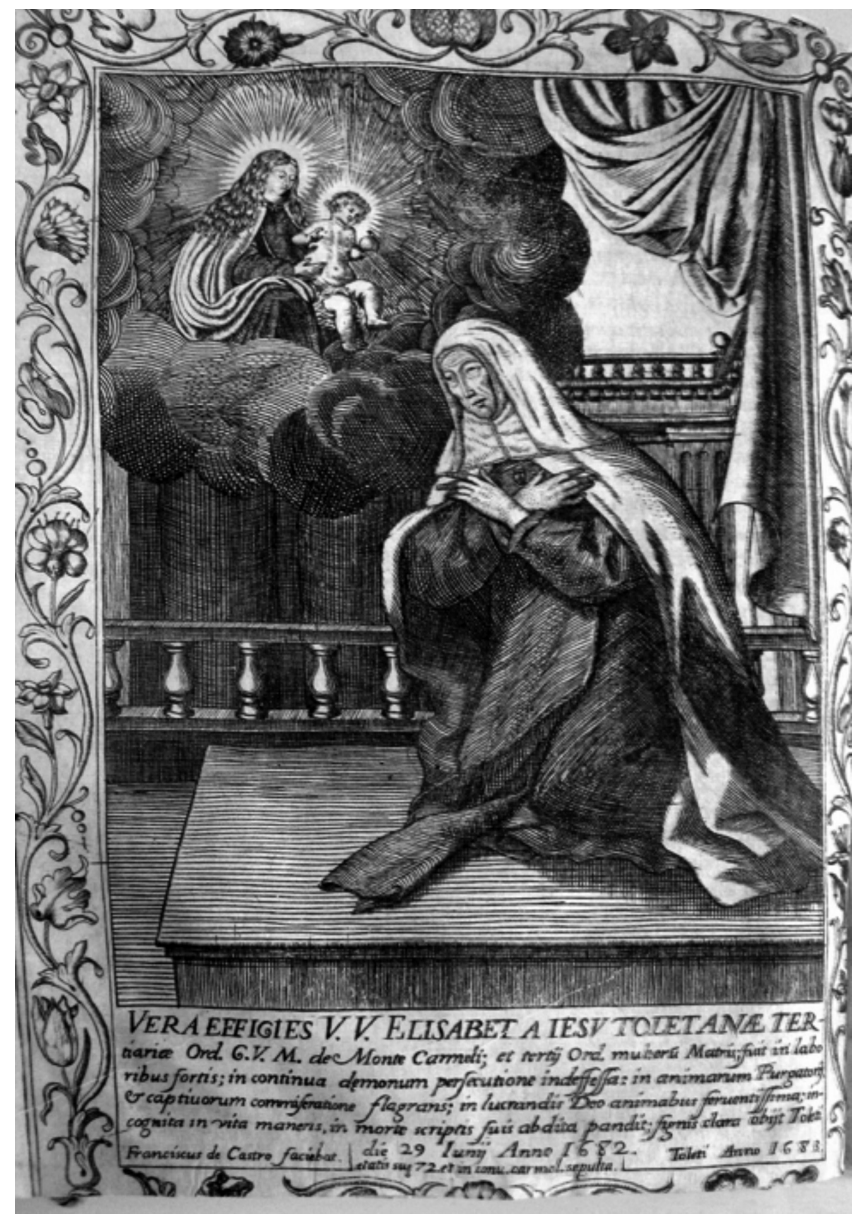

La Vida de la carmelita sor Mariana Francisca de los Ángeles (1637-1697), la escribió fray Alonso de la Madre de $\operatorname{Dios}^{45}$, carmelita descalzo, Lector, Prior y Predicador del convento de San Hermenegildo de Madrid. Sor Mariana fundó el convento de Santa Teresa de Madrid en septiembre de 1684, donde vivió como priora hasta los sesenta años, en

43 Isabel de Jesús 1685. Tesoro del Carmelo escondido en el campo de la Iglesia, hallado...; sacole à luz... Manuel de Paredes... de dicho Orden...: 234. En Madrid: por Julian de Paredes.

44 Ibídem 1685.

45 Alonso de la Madre de Dios 1763. Vida Histórico-Panegírica de.. Mariana Francisca de los Angeles... Carmelita Descalza...de Ocaña.. Fundadora de el de Santa Teresa de Madrid... / por el R. P. Fr. Alonso de la Madre de Dios...: Madrid: por Manuel Fernández. que murió en olor de santidad. Porque desde que ingresó como novicia en Ocaña inició un proceso de purificación mística con frecuentes arrobamientos, éxtasis y raptos, que incluía también severas penitencias, que con frecuencia le aplicaban los demonios. Estos la arrojaban por las escaleras, jugaban con su cuerpo a la pelota, y la llevaban al infierno donde la causaban todo tipo de tormentos. Incluso en cierta ocasión fue azotada por los ángeles como San Jerónimo. Fray Alonso dedicó el capítulo III del libro II a la "Afectuosa devocion, con que la V. Madre veneraba à Maria Santissima, à su Angel de Guarda, y otros santos». ${ }^{46}$ En él informaba que su ángel de guarda se llamaba Meliel, «que assi se lo dixo en algunos singulares coloquios sor Mariana». Fray Alonso también es permisivo con los ángeles apócrifos, porque argumentaba que aunque el Concilio del año 745 sólo admitió a los canónicos:

"No condena como improbable, que tengan otros nombres, diversos Celestiales espiritus; pues en el Libro 4.de Esdras (aunque no es Canonico) leemos el nombre de Uriel; y el Doctissimo Fray Pedro Navarro afirma, que el Angel Custodio de la V. sor Juana de la Cruz se llamaba ${\text { Lauriel} /{ }^{47}}^{4}$

FIGURA 7

Verdadero Retrato de la Venerable Madre Mariana Francisca de los Ángeles. Carmelita descalza y Fundadora de el Convento de Sta. Teresa de Madrid. "Is.de Palom. sculp. M\bti\s”. Grabado calcográfico. 1736.

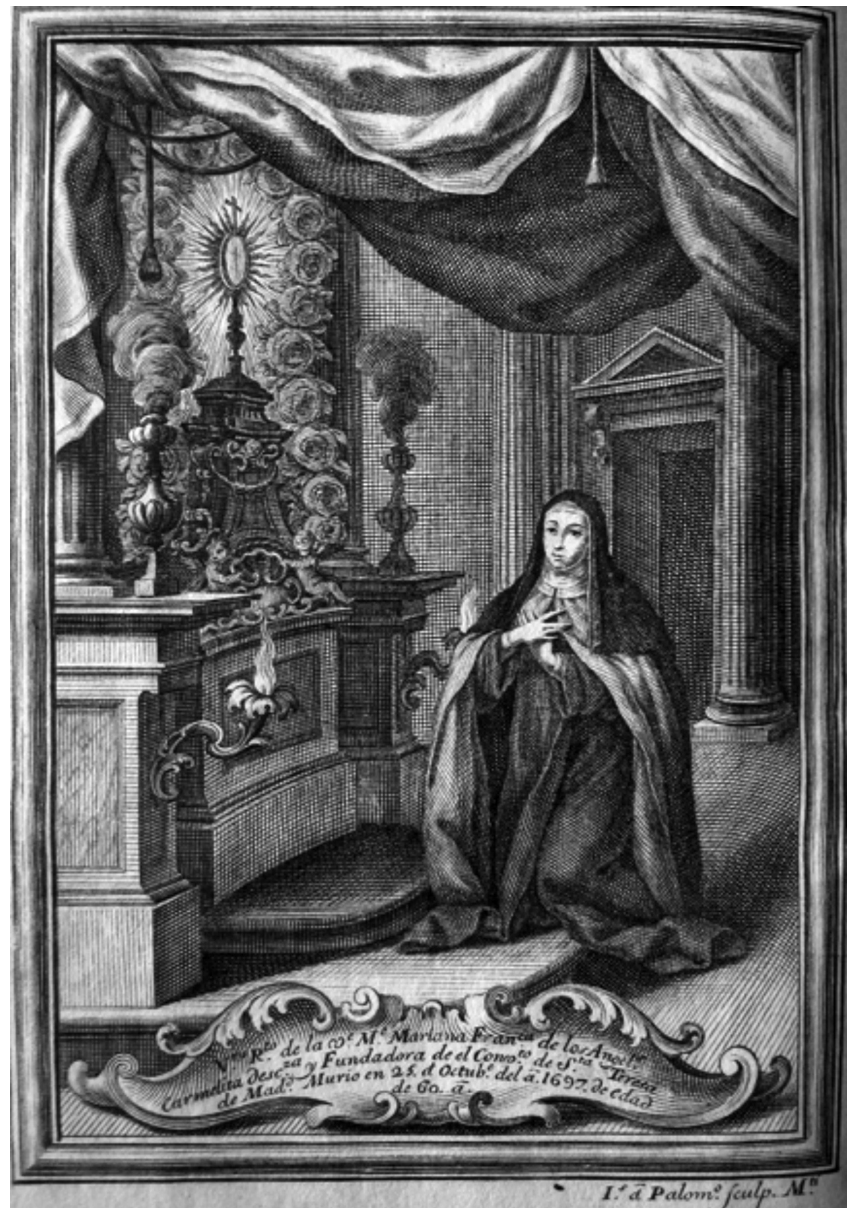

46 Ibídem. Libro II. cap. III: 309-321.

47 ídem. 
Doña Marina de Escobar (1554-1633) también fue agraciada con la custodia de ángeles apócrifos. Esta ilustre vallisoletana nunca profesó, pero fundó en España la orden de Santa Brígida y vivió toda su vida recluida en sus dependencias como una monja. Doña Marina se pasó los últimos treinta años de su vida postrada en una cama, recibiendo visitas de importantes personajes, y gozando de encuentros sobrenaturales, sueños místicos y visiones celestiales, que dictaba a sus compañeras de religión y al $P$. de la Puente, su confesor, quien recopiló sus escritos. ${ }^{48}$ Tan alta fue su consideración social, que incluso mantuvo una estrecha y constante relación con don Rodrigo Calderón, el hombre de confianza del Duque de Lerma, quien se dejó apresar siguiendo sus consejos. En la Vida de Doña María apenas existe una página donde no intervengan los ángeles; y una relación tan privilegiada con el mundo angélico, facilitó que le fueran asignados seis ángeles de guarda.

«Como N. Señor queria guiar a su sierva por caminos interiores, y tan nuevos y extraordinarios, quiso darla también Angeles especiales que la guiassen, y acompañassen en ellos por ser este su oficio [...] Primeramente desde luego començò a manifestarsela el Angel en figura de Niño de hasta diez años, muy hermoso, y resplandeciente [...] andando el tiempo (que seria a los 45 años de su edad) la dio otros quatro Angeles que la guardassen y asistiesen siempre en su compañia... los dos eran mayores en la apariencia, y los dos menores, con el excesso que haze un niño de diez años a otro de siete [...] Y porque los Santos Angeles, como consta de la Sagrada Escritura, toman los nombres de los oficios que hazen con los hombres, ellos la declararon sus nombres... el mayor se llamava Fortaleza de Dios, que es lo que significa Gabriel, porque la defendia valerosamente, y la preservava de los daños que el demonio pretendia hazerla, y el menor se llamava Rafael, que quiere dezir: Medicina de Dios: porque la curava de las llagas que el demonio la hazia, y la aliviava de sus dolores. Los otros dos del otro lado tenian conforme a su oficio, un nombre que declarava por este vocablo: missus maior y missus minor, embiados de Dios [...] En ocasión de otro gran aprieto [...] vino un Angel en forma de un niño de dos años [...] y preguntandola yo, si sabia el nombre, que avia tomado, dixo, Paranimpho [...] Finalmente N.Señor la dio otros quatro Angeles, que con un modo maravilloso estavan siempre con ella en su aposento, aunque no siempre los veia, como a los quatro primeros... ${ }^{49}$

Pero no solo existe constancia documental de que las monjas españolas adoptaban con frecuencia como custodios a los ángeles apócrifos. Sino de casos en que los representaron formando series. Así se deduce al menos del proceso seguido por la Inquisición contra las monjas del monasterio de San Plácido de Madrid, uno de los múltiples casos de posesión diabólica, que dio lugar a uno los procesos inquisitoriales más célebres del siglo XVII en España (1628-1660). ${ }^{50}$

48 Puente, Luis de la. 1665. Vida Maravillosa de la Venerable Virgen Doña Marina de Escobar natural de Valladolid, sacada de lo que ella misma escriuio de orden de sus Padres spirituales, Madrid, por Francisco Nieto. Y Pinto Ramírez, Andrés 1673. Segunda parte. Vida Maravillosa de la Venerable Virgen Dona Marina de Escobar, natural de Valladolid, sacada de lo que ella misma escribio, de orden de sus Padres Espirituales y de lo que sucedio en su muerte. Escrita por el Padre..., de la Compania de Jesus, que fue de Sacra Scriptura en el Colegio Real de Salamanca de la misma Compania, Madrid, Francisco Nieto.

49 Puente, Luis de la. 1665: 7-8.

50 Puyol Buil 1993.
FIGURA 8

\section{Visiones de $D \underline{a}$ Marina de Escobar. Seguidor de Diego Valentín Díaz (1586-1660). Convento de las Brigadas, Valladolid.}

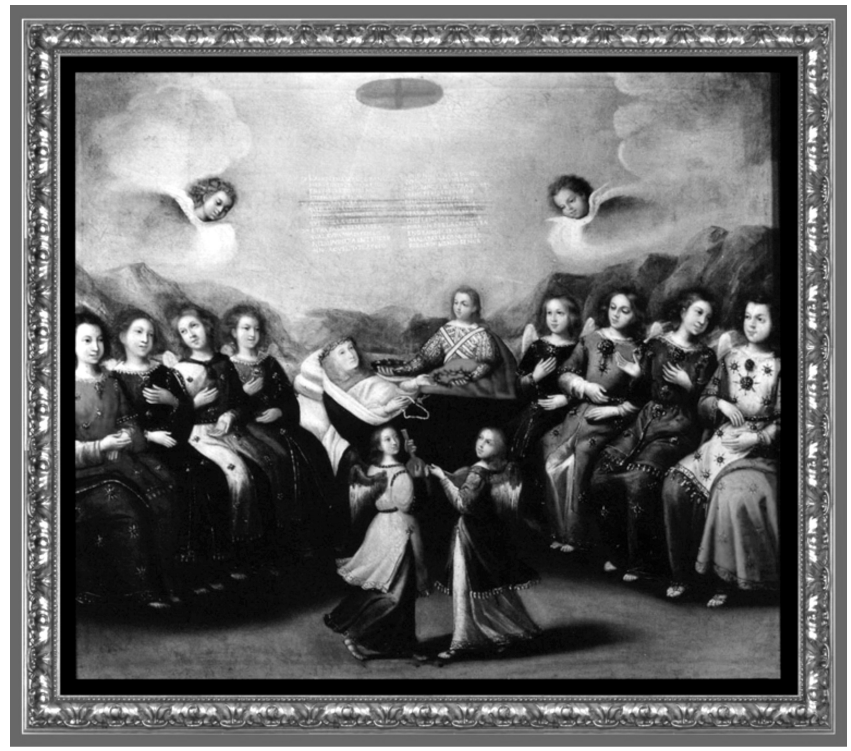

Estas posesiones eran frecuentes en aquella época, y solían justificarse como permitidas por Dios para probar la santidad de sus hijas predilectas. Con frecuencia los demonios las atormentaban física y espiritualmente para probar sus virtudes, pero tenían un especial interés en hacerlas perder su castidad, ya que era considerada la mayor virtud que podía ostentar una esposa de Cristo. Para conseguirlo utilizaban las más ardientes tentaciones carnales, y con frecuencia adoptaban formas de espantosos animales y de siniestros hombres, que las acosaban sexualmente y se apoderaban de diferentes partes de sus cuerpos. El remedio más eficaz para librar a un poseso de los demonios eran los exorcismos, pero también la intervención de sus ángeles custodios. Y por esa razón los de las monjas a veces eran varios, y siempre poderosos. Porque como afirmaba fray Pedro Navarro en la Vida de sor Juana de la Cruz, "Son aficionadísimos aquellos Espíritus celestes de las personas puras y vírgenes, y si con algunas especialmente se comunican, es con ellas». ${ }^{51}$

Pero el caso del monasterio de San Plácido de Madrid es particularmente interesante, porque las monjas adoptaron como custodios a unos ángeles apócrifos, cuyos nombres habían sido revelados por los demonios. El monasterio fue fundado en 1623 por el protonotario de Aragón, Don Jerónimo de Villanueva; su prometida, Doña Teresa Valle de la Cerda; y la tía de ésta, Doña Ana María de Loaysa, una mujer con fama de santa que tenía frecuentes "arrobamientos» y "hablaba cosas altísimas». Desde septiembre de 1625, Don Jerónimo de Villanueva, el prior, fray Francisco García, y casi todas las monjas, comenzaron a sentirse poseídos por unos demonios, que afirmaban «ser embajadores o ministros de Dios, forzados a entrar en las religiosas para enseñarles el camino de las virtudes y manifestarles los altos destinos que

51 Navarro, Pedro 1622 Lib. II. cap. V: 214. Favores de el rey de el cielo hechos a su esposa la Santa Juana de la Cruz...: con anotaciones theologicas y morales a la historia de su vida / por Fr. Pedro Navarro...: En Madrid: por Thomas lunti. 
ellas tenían en lo que llamaban «obra de Dios». ${ }^{52}$ Sus nombres eran Galalón, Herodes, Peregrinillo, Gallifarte, Astaroth, Taborlan, Serpiente Calculadora, Barrabas, La Borrica de Balam, etc. y profetizaban una reforma de la Iglesia, en línea con los movimientos milenaristas, los alumbrados y los místicos. En el dossier del Proceso queda constancia que estos demonios describieron con todo detalle los nombres y las insignias de los ángeles de la guarda de varias monjas, y de algunas personas relacionadas con el monasterio:

"Item haviendo el demonio declarado algunos nombres de los Ángeles de guarda que el Reo y otras ciertas personas tenían, llamándoles nombres insólitos y no reçividos en la iglesia Catholica, como Çarça Dei, Rosauro, Uriel, Lauro y otros $\|^{53}$

«Dixo que solo del de Uriel tenia notica y que de todos los demas que eran muchos (como ha declarado) ni los avia oido, leido ni imaginado ${ }^{54}$

Nadie de la comunidad puso reparos a estos nombres, e incluso se decidió representarlos en cuadros para instalarlos en los claustros.

«En lo de los Ángeles, es que no sólo los Ángeles que declaró ésta, mas en todos los que dixeron los Demonios de Josefa María y Ana de Tejada se dio credulidad por todos según apariencia y, que con el parecer de fray francisco diciendo que se hiciese, lo harían, y determinadamente dixo el dicho fray francisco, que se pintasen los ángeles suyo y de las demás Religiosas, y del P. Fray Juan de Baraona y de todos los demás y que se avían dicho para ponerlos en el Claustro, y se sacaron de los Cartapacios, los quales estaban escritos de mano de fray francisco, y las copias de los Ángeles que para pintarlos se sacó, la escribió y pintó fray Juan de Baraona, y parte de ellos se dio a un pintor para pintar los escritos, las insignias y los nombres ${ }^{55}$

Los cuadros de Lauro, custodio de Don Jerónimo de Villanueva, y de Uriel, custodio de fray Facundo de Torres, se encargaron a un modesto pintor de origen italiano llamado Julio César Semín, que había participado en la decoración del Ochavo del Alcázar y del Palacio del Pardo. Como en el caso del Proceso contra Francisco Barreda, los calificadores de la Inquisición censuraron los nombres y las insignias de los ángeles, en base, como siempre, a la condena del concilio romano del 745; pero disculpaban a casi todos los procesados, por entender que las cuestiones relativas a los ángeles apócrifos eran desconocidas para la mayoría de la gente. Así leemos como fray Alonso de León, monje benito de Sahagún, declaró que no le causó extrañeza la pintura del ángel de Don Jerónimo de Villanueva «por aver visto en el oratorio de la Condesa Nieva pintados dos Ángeles, que decían eran de Doña Marina de Escobar, y entraba allí gente docta». ${ }^{56}$ Fray Alonso no precisa cuál de los cinco ángeles custodios de Doña Marina, eran los dos que estaban representados en el oratorio de la condesa de Nieva, pero es de suponer que alguno de los apócrifos, puesto que los canónicos no tenían porqué causar extrañeza a nadie.

\footnotetext{
52 Puyol Buil 1993: 151.

53 Ibídem: 394. [Audiencias, fol. 48 r./v.]

54 Ibídem: 165 [Declaraciones de 6.7.1628 en San Placido ante Diego Serrano. A.H.N. Inq. Leg.3691, caja 1, fol. 259 v.-260r.]

55 Cordero de Ciria 1997: 76.

56 Ibídem 1997: 77.
}

\section{LOS ÁNGELES APÓCRIFOS EN AMÉRICA}

De lo expuesto se deduce que los ángeles apócrifos eran relativamente frecuentes en España, mucho antes de que se representaran en América, como por otra parte sería lo habitual en las relaciones entre un reino y sus virreinatos. Y por muy sugerente que resulte considerarlos pervivencias de sistemas angélicos heterodoxos, o producto del sincretismo religioso entre los cultos cristianos y los andinos, la realidad parece ser mucho más sencilla y palmaria. Porque tanto los textos como las imágenes indican, que no es necesario buscar sus fuentes ni su significado fuera de la doctrina católica. Y que estas «enigmáticas» series, que por otra parte constituyen una de las más importantes peculiaridades del barroco hispanoamericano, no ocultan extraños misterios ni mensajes indescifrables, sino que fueron creadas a instancia de las monjas españolas, conforme a lo que era usual en la doctrina angélica de su época.

Por lo que sabemos, las series de ángeles apócrifos alcanzaron su mayor expansión en Andalucía, y muchas de ellas debieron ser realizadas por seguidores de Zurbarán, como Bartolomé de Ayala y los hermanos Polanco. Series similares se exportaron a los virreinatos americanos, como la que envió Bartolomé Román al Colegio de los jesuitas de Lima, replica de la que realizó para las Descalzas; y a imitación de las series españolas, los artistas americanos realizaron sus propias series. En la iglesia de Santa Bárbara de Tunja (Colombia) se conservan doce cuadros de ángeles, estilísticamente muy similares a los de la catedral de Jaén, y del Hospital del Pozo Santo, y que sin duda debieron ser encargados por algún ilustre tunjano a los artistas andaluces. Como los arcángeles Salatiel y Magaliel conservados en el Museo Nacional de Bogotá, seguramente restos de alguna serie; el primero casi una réplica del Ángel con espada de la serie de la catedral de Jaén; y el segundo, del Alamiel Pax Dei del Hospital del Pozo Santo. ${ }^{57}$ No se sabe cuando se instalaron los cuadros en la iglesia de Santa Bárbara, ni cuántos de ellos constituían la serie. Según Consuelo Jaramillo ${ }^{58}$ tres cuadros se encuentran en la nave de la iglesia, uno en la capilla de Nuestra Señora del Carmen, y ocho en la capilla de la Virgen del Pilar, que fue patrona de Tunja durante el virreinato. Jaramillo identificó entre ellos a Uriel, Esriel y Jehudiel, pero no explica si los nombres los dedujo de su iconografía, o figuraban inscritos en los cuadros. Si nos basamos tan solo en su iconografía, los ángeles de la capilla del Pilar serían Miguel, Gabriel, Rafael, Ángel con la espada flamígera. Ángel con corona y palma, Ángel con flama, Ángel con columna, y Ángel envainando la espada. Los de la nave de la iglesia, Rafael, Ángel con corona y cetro y Ángel envainando la espada. Y el de la capilla del Carmen, Gabriel. La capilla del Pilar, donde están instalados la mayoría, embutidos en una retablera horizontal del mismo estilo que el retablo de la Virgen, se construyó en 1686. Y según Rodolfo Vallin ${ }^{59}$ los cuadros no han figurado nunca ni en los Libros de Fábrica ni en los Libros de la Cofradía, que desapareció en 1872. La capilla fue dorada y estucada en 1889 , fecha en la que bien pudieron llegar a la iglesia los cuadros procedentes quizás de las desamortizaciones de los conventos femeninos de Tunja.

57 Ver Gamboa Hinestrosa 1996: 76.

58 Jaramillo Obando 1995.

59 Vallín, Rodolfo "Santa Bárbara en Tunja, Colombia», en https:// juanbartigas.files.wordpress.com/2012/05/3-santa-bc3a1rbara-entunja-colombia.pdf Visto 26-11-2015. 
FIGURA 9

San Miguel. Siglo XVII. Escuela andaluza. Serie de la capilla del Pilar de la iglesia de Santa Barbará de Tunja (Colombia).

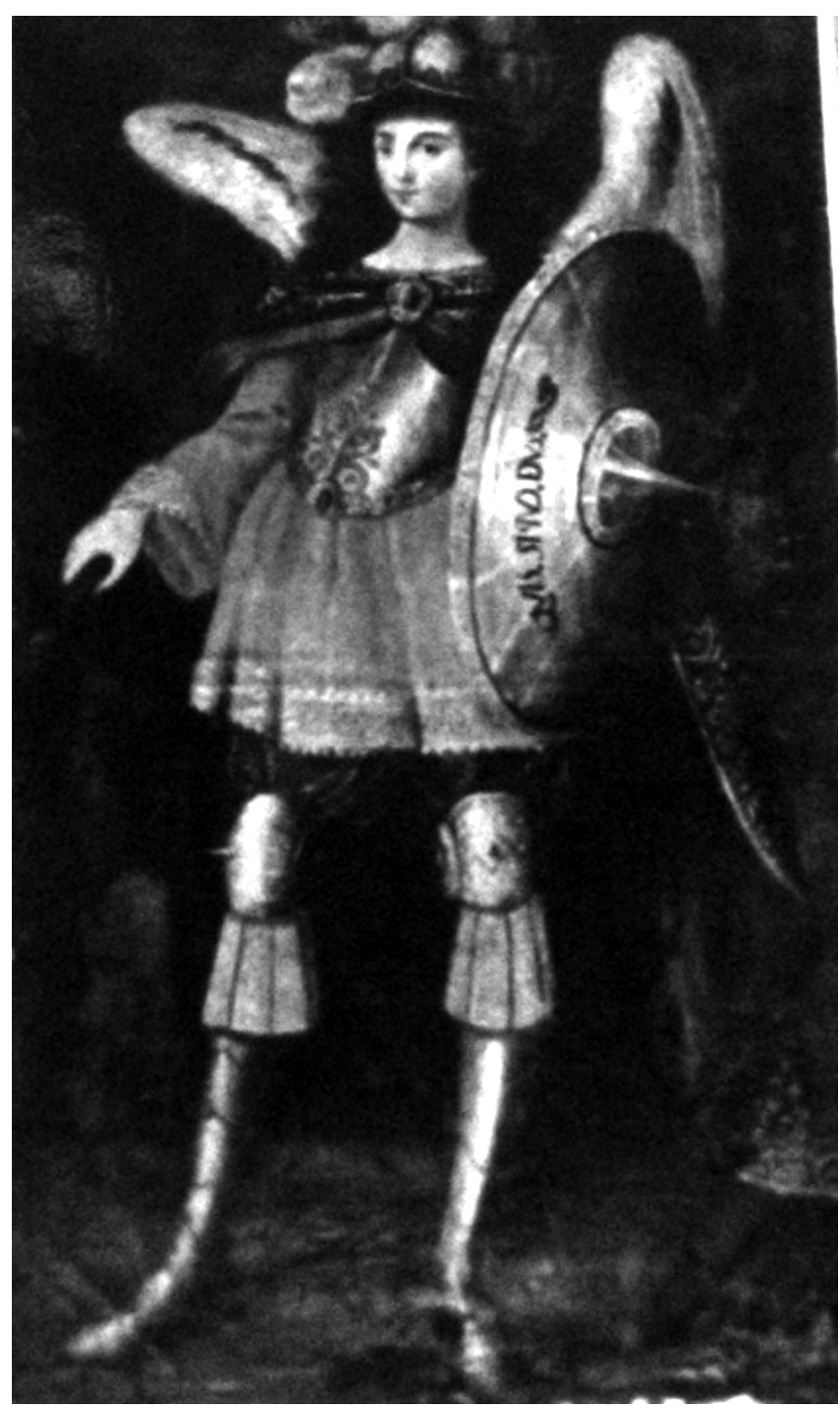

Porque al parecer ese pudo ser también el caso de la serie más conocida de Colombia, la conservada en la iglesia del Divino Salvador de Sopó, al parecer instalada también en la iglesia a mediados del siglo XVIII. La serie fue estudiada por Santiago Sebastián ${ }^{60}$, Consuelo Jaramillo ${ }^{61}$, Gutiérrez Vallejo y Gamboa Hinestrosa ${ }^{62}$ entre otros. Los historiadores colombianos defienden la tesis de que la serie fue importada de otros países, o realizada por un artista de formación europea ${ }^{63}$; mientras que Sebastián la atribuye a un artista virreinal, quien se habría basado en grabados europeos para realizarla. La serie no aparece documentada hasta el inventario parroquial de $1847^{64}$, y está formada por doce cuadros que representan ángeles de aspecto muy femenino, muchos de ellos en posturas sensuales, identificados con nombres apócrifos e inscripciones latinas: Miguel, Gabriel

\footnotetext{
60 Sebastián López 1987.

61 Jaramillo Obando 1995.

62 Gamboa Hinestrosa 1996.

63 Ibídem: 1996: 143.

64 Jaramillo Obando 1995: 263.
}

Fortitudo Dei, Rafael Medisina Dei, Uriel Ignis Dei, Barachiel Benedictio Dei, Geudiel Penitentia Dei, Seactiel Oratio Dei, Laruel Misericordia Dei, Esriel Justicia Dei, Piel Decus Dei, Teadkiel Potentia Dei, y Ángel Custodio. Según Gamboa esta serie tan numerosa de ángeles de un tamaño tan considerable, no debió ser encargada por la parroquia, sino por alguna institución religiosa de Santa Fe de Bogotá. Y como la zona donde se asienta Sopó fue evangelizada por la Orden de Predicadores, y la mayoría de los cuadros existentes en el templo son de santos dominicos, Gamboa piensa que la serie se trasladó a Sopó a mediados del siglo XVIII desde el convento de Santo Domingo, coincidiendo con la aparición de la imagen milagrosa del Señor de Sopó en 1753, con la reconstrucción de la iglesia, y con los graves daños que sufrió el convento dominico en los sismos de 1743 y 1785.

Pero sería más prudente pensar que si los cuadros proceden de algún recinto dominico, este debió de ser el convento de las monjas de Santa Inés de Montepulciano, y no del de frailes de Santo Domingo. Y esto por varias razones. En primer lugar, porque la preeminencia de las series de ángeles apócrifos en conventos femeninos es absoluta, y en conventos de varones, tan solo conocemos las de los Siete Príncipes del monasterio de San Jerónimo de Granada y del Colegio jesuita de Lima (Perú). En segundo

FIGURA 10

Uriel Ignis Dei. Siglo XVIII. Serie de la iglesia del Divino Salvador de Sopó (Colombia).

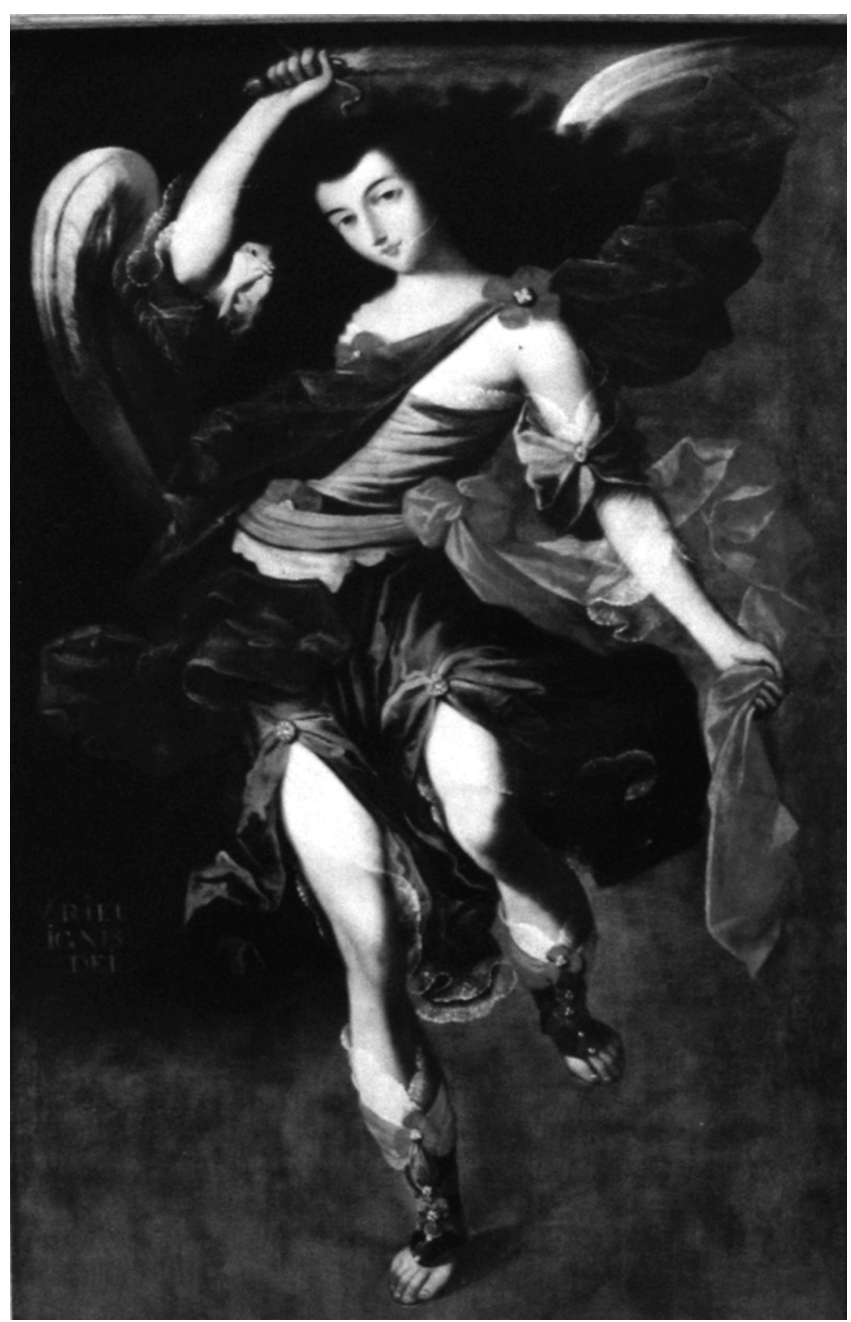

Hispania Sacra, LXIX 140, julio-diciembre 2017, 647-660, ISSN: 0018-215X, doi: 10.3989/hs.2017.040 
lugar, porque es difícil imaginar que ningún responsable de la orden, permitiese la presencia de ángeles tan femeninos y tan sensuales en un convento de hombres. Y en tercer lugar, porque aunque son frecuentes las representaciones de ángeles con coronas de flores, es significativo que las monjas también los ostenten en sus retratos mortuorios.

Donde sí se sabe con seguridad que hubo una serie de ángeles apócrifos fue en el convento de clarisas santafereño, que tras su desamortización en el siglo XIX se reconstruyó y pasó a ser Facultad de Bellas Artes, Centro de Restauración y sede del Ministerio de Cultura. ${ }^{65}$ En el presbiterio de la iglesia, ocupando una retablería horizontal, todavía se conservan nueve cuadros de ángeles también de aspecto muy femenino, en los que se aprecian similitudes con los de Sopó y con los grabados flamencos. Dos representan a San Miguel, y el resto constituyen una serie de los Siete Príncipes, en la que Baraquiel se ha sustituido por el Ángel de la Guarda. La serie fue incluida por Consuelo Jaramillo ${ }^{66}$ en su tesis doctoral y publicada por María Eugenia Cerón y Nora Lucía Montaño en 2005. ${ }^{67}$

FIGURA 11

San Gabriel. Siglo XVIII. Serie de la iglesia de Santa Clara de Bogotá (Colombia).

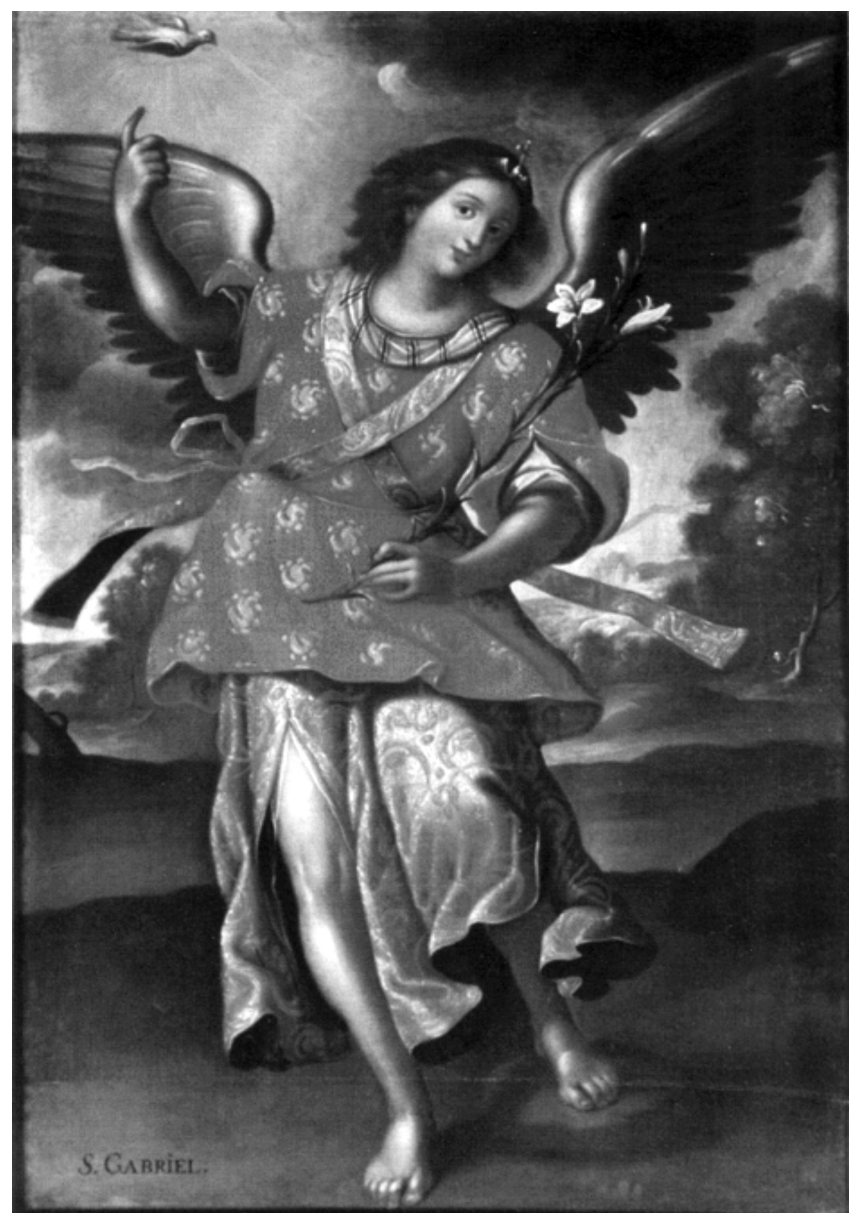

65 Ver Mercedes Medina de Pacheco. «Conventos de Santa Fe de Bogotá, siglos XVI y XVII», publicado en http://mercedesmdepblog.com/ el 18.2.1015.

66 Jaramillo Obando 1995: 281-290.

67 Cerón Sanclemente 2005.
También los ángeles apócrifos se emplazaron en los conventos femeninos peruanos. Al monasterio de la Encarnación, regentado por las Concepcionistas Franciscanas de Copacabana, llegó a finales del siglo XVII una serie de siete ángeles, que los historiadores peruanos atribuyeron a Zurbarán, y los españoles a Ignacio de Ries y Francisco Polanco. ${ }^{68}$ La serie está formada por Miguel, Gabriel, Rafael, Uriel, Ariel, Hadriel y Zadquiel; y es muy probable que representen a los Siete Príncipes, aunque tres ángeles figuren con otros nombres. En los cuadros figuran los nombres de los ángeles, advocaciones en latín que nadie ha dado a conocer hasta ahora, y escenas en miniatura alusivas a la identidad del ángel, como en la serie de Aguilar de la Frontera (Córdoba). Miguel se representa con la escena de su lucha con el dragón; Gabriel con la

FIGURA 12

Zadquiel. Atribuido a Francisco Polanco (+1651). Serie del monasterio de la Concepción de Lima (Perú).

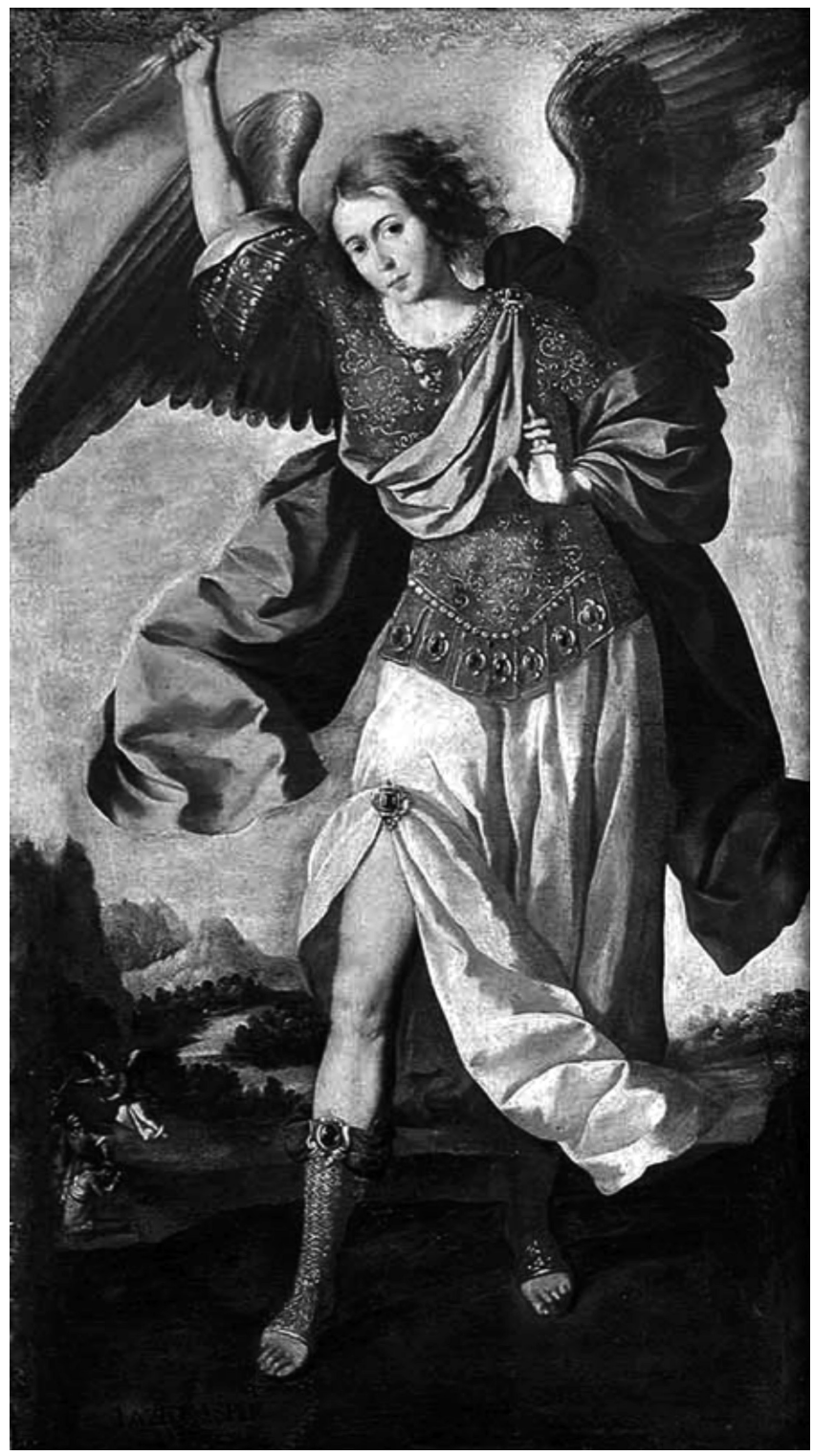

68 Valdivieso 1992 y Navarrete Prieto 1998: 61-67. 
Anunciación; Rafael con la que acompaña a Tobías; Uriel con la expulsión del Paraíso; Ariel con la escena del ángel instruyendo a Esdras; Hadriel, con la aparición del ángel a David para anunciarle la peste; y Zadquiel con el sacrificio de Isaac. No sabemos si los nombres y las inscripciones los incluyó el pintor que realizó la serie en España, o fueron añadidos posteriormente en Lima; pero es más probable lo primero, ya que Ariely Hadriel también figuran en la serie del Hospital del Pozo Santo (Sevilla) con los mismos atributos que en la de Lima. La serie se conservó hasta hace poco tiempo en la iglesia del monasterio, que sufrió gravísimas mutilaciones para construir el Mercado Central y ampliar la Av. Abancay, pero recientemente se trasladó junto a las monjas a su nueva sede en un pueblito al norte de Lima. ${ }^{69}$ Otro convento peruano que conserva una serie angélica es el de las clarisas de Trujillo, de la que sólo sabemos que son ángeles arcabuceros inmaculistas, representados tal vez para combatir las legiones de demonios que se posesionaron de las monjas, como se constata en el citado proceso de la Inquisición contra Juana Luisa Benítez y Ana Núñez.

\section{CONCLUSIONES}

De lo expuesto se deduce que quienes iniciaron y propagaron las series de ángeles apócrifos del periodo Barroco, fueron las monjas españolas; y que por tanto, no surgieron en los virreinatos americanos, sino en España. Si la devoción angélica se usó para cristianizar cultos precolombinos, no viene al caso, porque desde que el mundo es mundo, ha sido práctica habitual el sincretismo religioso en todas las conquistas. Por otra parte, estas representaciones angélicas no deben vincularse con sistemas angélicos heterodoxos, sino que deben considerarse alegorías de atributos divinos, oficios y beneficios angélicos, que es lo que se deduce de su iconografía y de los textos de la época. La presencia de los ángeles apócrifos en los conventos femeninos, se debía sencillamente a la notoriedad y permisividad de que gozaban los nombres apócrifos, y a la necesidad que tenían las monjas de dirigirse a sus ángeles custodios por sus nombres, y de representarlos en imágenes.

$Y$ esos ángeles son los que con el paso del tiempo volaron hacia los virreinatos americanos, y no los que figuran en el Libro de Enoch, en otros textos apócrifos, o en otros sistemas angélicos, como afirman los historiadores suramericanos. Y prueba de ello es la sorprendente similitud de algunos nombres apócrifos de las series españolas y americanas, que en ocasiones parecen los mismos nombres con pequeñas variaciones fonéticas locales, incluidas las series tan genuinamente andinas como las de los ángeles arcabuceros. $Y$ junto a los nombres viajaron también los atributos, como se aprecia al comparar los que exhiben estos ángeles a ambos lados del Atlántico.

\footnotetext{
69 Comunicación de Escardiel González Estévez.
}

CUADRO 2

Nombres apócrifos similares en las series angélicas españolas y americanas.

No se incluyen los apócrifos de los siete príncipes

\begin{tabular}{|l|l|}
\hline \multicolumn{1}{|c|}{ NOMBRE } & \multicolumn{1}{c|}{ SERIE } \\
\hline Ariel & $\begin{array}{l}\text { Pozo Santo. Concepción Lima. } \\
\text { Col. part. Lima }\end{array}$ \\
\hline Alamiel Salamiel & $\begin{array}{l}\text { Pozo Santo. Calamarca. Uquia. } \\
\text { Col. part. Lima }\end{array}$ \\
\hline Adriel. Hadriel. Habriel & $\begin{array}{l}\text { Pozo Santo. Concepción Lima. } \\
\text { Challapampa Calamarca. Uquia. } \\
\text { Col. part. Bolivia }\end{array}$ \\
\hline Eliel & Pozo Santo. Uquia. Museo Arte Lima \\
\hline Esriel & Pozo Santo. Sopó. Col. part. Lima \\
\hline Leriel & Aguilar de la Frontera. Calamarca \\
\hline Oziel. Osiel. Osriel. Hosiel & $\begin{array}{l}\text { Pozo Santo. Calamarca. Uquia. } \\
\text { Col. part. Lima }\end{array}$ \\
\hline
\end{tabular}

CUADRO 3

Atributos que portan los ángeles apócrifos en series españolas y americanas

\begin{tabular}{|c|c|c|c|}
\hline POZO SANTO & $\begin{array}{l}\text { AGUILAR DE LA } \\
\text { FRONTERA }\end{array}$ & TUNJA & CALAMARCA \\
\hline $\begin{array}{l}\text { Corona y cetro } \\
\text { Rama de olivo } \\
\text { Llave } \\
\text { Envainando } \\
\text { espada } \\
\text { Haz de llamas } \\
\text { Columna partida } \\
\text { Palma y flores }\end{array}$ & $\begin{array}{l}\text { Rama de olivo } \\
\text { Llave } \\
\text { Envainando } \\
\text { espada } \\
\text { Haz de llamas } \\
\text { Columna partida } \\
\text { Espada flamígera } \\
\text { Haz de espigas }\end{array}$ & $\begin{array}{l}\text { Corona y Palma } \\
\text { Envainando } \\
\text { espada } \\
\text { Haz de llamas } \\
\text { Columna partida } \\
\text { Espada flamígera }\end{array}$ & $\begin{array}{l}\text { Corona y cetro } \\
\text { Llave } \\
\text { Envainando } \\
\text { espada } \\
\text { Haz de llamas } \\
\text { Columna partida } \\
\text { Espada flamígera } \\
\text { Haz de espigas } \\
\text { Flores }\end{array}$ \\
\hline
\end{tabular}

\section{BiBLIOGRAFÍA}

Ávila Vivar, M. 2011. «Relaciones del P. Jerónimo Gracián con las series angélicas de los monasterios reales madrileños. Origen y evolución de las series de los siete príncipes de los ángeles». Reales Sitios 189: 52-72.

Ávila Vivar, M. 2014. «La serie de ángeles del monasterio de San José y San Roque de Aguilar de la Frontera (Córdoba)». Ucoarte 3: 35-47.

Ávila Vivar, M. 2016. Angelología Barroca. Las Series Angélicas. Barcelona: Edición del autor.

Braccio, G. 2010. "San Laruel Aureo, una imagen controvertida», en Comunicación en Congreso 2010 de la Asociación de Estudios Latinoamericanos: del 6 al 9 de octubre de 2010. Canadá: Toronto. http://lasa.international.pitt.edu/members/congress-papers/ lasa2010/files/3928.pdf. Leído 18.11.2013.

Cerón Sanclemente, M.a E. 2005. La Hueste Angélica de Santa Clara. Bogotá. Universidad Distrital Francisco José de Caldas.

Cordero de Ciria, E. 1997. "Arte e Inquisición en la España de los Austrias». Boletín del Museo e Instituto "Camón Aznar» 70.

Fernández López, J. 1991. Programas iconográficos de la pintura barroca sevillana del siglo XVII. Sevilla: Universidad de Sevilla.

Gamboa Hinestrosa, P. 1996. La pintura apócrifa en el arte colonial. Los arcángeles de Sopó. Bogotá: Editorial Universidad Nacional.

González Estévez, E. 2012. «De fervor regio a piedad virreinal. Culto e iconografía de los Siete Arcángeles». SEMATA, Ciencias Sociais e Humanidades 24: 111-132.

Gonzalo Rubio, C. 1977. La angelología en la literatura rabínica y sefardí. Barcelona: Ameller Ediciones. 
Jaramillo Obando, C. 1995. El Arte barroco español y el arte colonial colombiano en las series angélicas. Tesis doctoral inédita. Madrid: Facultad de Bellas Artes de la Universidad Complutense.

Kusche, M. 2003. Retratos y Retratadores Alonso Sánchez Coello y sus competidores: Sofonisba Anguissola, Jorge de la Rúa y Rolán Moys. Madrid: Fundación de Apoyo a la Historia del Arte Hispánico.

Lara Arrebola, Fco. 1980. «Bernabé de Ayala y la serie de ángeles del monasterio de San José y San Roque de Aguilar de la Frontera». Boletín de la Real Academia de Córdoba, Año L. 101: 195-211.

Mesa, J. y Gisbert, T. 1976. "Las series de ángeles en la pintura virreinal». Revista Aeronáutica: 59-66.

Mesa, J. y Gisbert, T. 1983. Los ángeles de Calamarca. La Paz: Compañía boliviana de Seguros.

Mujica Pinilla, R. 1996. Ángeles apócrifos en la América virreinal. Lima: Fondo de Cultura Económica.
Navarrete Prieto, B. 1998. La pintura andaluza del siglo xvII y sus fuentes grabadas. Madrid: Fundación de apoyo a la historia del arte hispánico.

Pérez Villanueva, J. 1979. "Sor María de Agreda y Felipe IV: un epistolario en su tiempo», en Historia de la Iglesia en España: La Iglesia en la España de los siglos XVII y XVIII. IV. Madrid: Editorial Católica.

Puyol Buil, C. 1993. Inquisición y política en el reinado de Felipe IV: los procesos de Jerónimo de Villanueva y las monjas de San Plácido 1628-1660. Madrid: Consejo Superior de Investigaciones Científicas.

Sebastián López, S. 1987. Arcángeles de Sopó. Bogotá: Banco de la República.

Valdivieso, E. 1992. «Ángeles sevillanos en Lima». Buenavista de Indias 6: 34-45. 